\title{
Environmental Compliance and Human Capital: Evidence from Chinese Industrial Firms
}

Jing Lan

National Graduate Institute for Policy Studies, Tokyo, Japan

\author{
Alistair Munro \\ National Graduate Institute for Policy Studies, Tokyo, Japan
}

Abstract: By using a unique cross-sectional dataset of Chinese industrial firms, this paper investigates the external and internal effects of human capital on firms' environmental performance. The result shows that firms have better environmental compliance because they are 'pushed' into making compliance decision by internal driver of human capital and 'pulled' to be environmental friendly by external force of social human capital stock. This finding is robust when we take into account of possible endogeneity of human capital. In addition, evidence from this study suggests that the situation of weak implementation of environmental supervision and evasion of environmental monitoring could be reconciled by internal and external effects of human capital.

JEL classification: Q02; Q52; Q55

Keywords: Environmental compliance; Human capital; External and internal effects; Endogeneity

\section{Introduction}

The increasingly serious industrial pollution poses a challenge to China's fast economic growth. Despite well-conceived laws, enforcement varies tremendously on the ground (Wang et al. 2003, Wang and Wheeler, 2005). Local governments' focus on economic growth and firms' resistance towards additional compliance have both brought about weak implementation (SEPA, 2006). Given this situation, it is important to understand the drivers behind compliance with environmental regulations. In this paper, we attempt to find empirical evidence on the factors behind compliance by using a unique environmental performance data of 2544 industrial Chinese firms. There is already a large literature on regulatory compliance. Our particular focus is on the relationship between human capital and compliance which we consider a neglected aspect of the existing research. Conceptually, the relationship between human capital and industrial pollution can be through either an internal or an external route. Within the firm, the implementation of abatement technology is determined by the absorptive capacity of internal human capital endowment, the higher the level of human capital, the better application within the firm. Outside the firm, higher educated people are more likely to tighten the stringency of environmental regulations by imposing pressure on environmental regulators. Based on the above descriptions, we hypothesize that (i) the internal effect of human capital pushes firms to voluntarily comply with environmental regulations and (ii) by enhancing regulatory pressure, the external effect of human capital also pulls firms to have better environmental performance.

We aim to make three contributions to the existing literature. First, this paper sheds light on the internal and external effects of human capital on firms' environmental performance. Our results show that firms have better environmental performance because they are 'pushed' into making compliance decision by internal endowment of human capital, and 'pulled' by external forces of social human capital stock. Accordingly, better environmental performances are achieved based on the internal and external drivers of human capital. 
Second, we take into account the possible endogeneity of both external and internal human capital. From the internal side, as shown by Grolleaua et al. (2012), environmental-related standard (i.e. ISO 14001 standard) tend to improve the recruitment of professional employees. Such enhancement implies that better environmental performance deliver more than environmental benefits and firms can strategically use them for their ability to generate attractions to high educated or high skilled employees who are more sensitive to environmental protection. From the external side, higher educated people may move to cleaner cities since they are more sensitive to environmental quality. These issues have further interest given a potential two-way causality between human capital and environmental performance. Most of studies to be reviewed in section 2 do not concern the endogeneity of human capital; our study on the other hand, better identifies the causal relationship between environmental performance and human capital.

Third, in order to do our analysis we build a new database of firm-level data for China. Blackman and Kildegaard (2010) argue that most studies in developing countries rely on selfreported firm-level environmental data. However, instead of self-reported one, the environmental performance data we use in this paper is evaluated and compiled by government environmental administration. The environmental performance might be different from regulator-reported than self-reported. Thus, our study may fill gap in the literature by providing evidence from the regulator-reported environmental data of Chinese industrial polluters.

The remainder of the paper is organized as follows. In section 2, we give a brief review of related literature on environmental performance and human capital, highlighting their connection though internal and external paths. Section 3 presents the data and explains the empirical methodology. Section 4 estimates the econometric models and discusses the results obtained. The final section concludes and derives policy implications.

\section{Related literature}

Human capital is an important internal factor that drives firms to voluntarily comply with environmental regulations. In order to adopt new technologies, firms must have corresponding stock of human capital to acquire the requisite technical and economic information. Information acquisition may be passive, with firms absorbing information via day-to-day contact with business associates, or it may be active, with firms engaging in training and technical extension program. In either case, information acquisition is greatly facilitated and accelerated by the firm's pre-existing stock of human capital, that is, the education and training of the employment. Therefore, empirical studies of green technologies adoption typically find that firms with more human capital are more likely to adopt new technologies of abatement and have better environmental performance, all other thing being equal. For instance, in their study of Indonesian water polluters, Pargal and Wheeler (1996) find that average education level of employment is correlated with lower emission of water pollutant. Dasgupta et al. (2000) analyze the extent of adoption of ISO 14001 type environmental management practice by firms in Mexico. They show that firms with highly educated workers have significantly greater environmental management effort and compliance. Gangadharan (2006) also yields a further confirmation of the positive role of internal human capital on firms' environmental performance survey evidence from manufacturing industries in Mexico. Manderson and Kneller (2012) suggest that firms with a greater intensity of human capital may have greater opportunities for technological advancement of pollution abatement though they fail to find significant result. Blackman and Kildegaard (2010) use original firm-level survey data to identify the factors that drive Mexican firms' adoption of clean technologies and find that the key driver of adoption is the firms' human capital.

The external effect of human capital on firms' environmental performance through community pressure has also been mentioned and studied in the literature. As Fishel (1979) and Nelson et al (1966) claim that people with higher education are more likely to be more aware of and evaluate 
environmental issues differently than do those with less education, people with high human capital are revealed to be more sensitive to surrounding environmental quality. Goetz et. al (1998) argue that changes in human capital modify individuals' appreciation of environment independently of income, thereby causing changes in behavior that are measurable at the state level in the United States. They also show that educated decision-makers are more likely engage in community activities that improve the environment and persuade manufacturers to make effort in pollution abatement since those people are more likely to be aware of detrimental effects of environmental pollution on their health. Goldar and Banerjee (2004) find that the percentage change in the local literacy rate help explain water quality in river sections downstream from Indian industrial clusters. In the case of China, Dasgupta and Wheeler (1997) analyze the determinants of citizens' complaints in 29 Chinese provinces and find that they are an increasing function of the levels of education. Dasgupta et al. (2001) show that informed citizens can have an important impact on pollution via inspections by using a panel data of major polluters from Zhenjiang city and they suggest that regulators to embark on education policies to control pollution. Cole et al. (2008b) examine the possible factors that may influence industrial pollution emissions in China by using a panel of 15 industries and their results suggest that regions with greater levels of education may have more stringent regulations.

In addition to the possible better environmental performance resulting from efficient absorption and effective adoption of clean technology by human capital, several other studies have examined whether and how environment-related standards improve human resource management. Firms may adopt voluntary environmental initiatives to improve human resource management by facilitating recruitment, increasing employees' morale and motivation, and thereby raising workforce productivity (Halkos and Evangelinos, 2002). Mzoughi et al. (2007) test their hypothesis that the probability of registering for a certified EMS increases as the firm wants to improve its human resource management and their results show that ISO 14001 registration among French agrofood firms was mainly driven by the desire to improve human resource management. More recently, Grolleaua et al. (2012) investigate the impact of environmental-related standards on employees' recruitment using a bivariate probit model and their result show that firms can benefit from self-reinforcing effects and strengthen their greenness by attracting environmentally sensitive talent employees. Therefore, it is necessary for us to take into account the endogeneity of firms' environmental performance on corresponding human capital level.

\section{Empirical methodology and data}

\subsection{The environmental performance data}

The firm level data employed in this paper are compiled from State Bureau of Environmental Protection and China's industrial enterprises database (survey data 2004); the city-level data are compiled from China Environmental Statistics Yearbook (2005), and sector level data are sourced from China Industrial statistics yearbook (2005). The original environmental performance rating data set is drawn from the environmental information disclosure system data (2004) of State Bureau of Environmental Protection with a total 3729 firms from SIC 4-digit industrial sectors covered 29 cities, 9 provinces (including autonomous regions and municipalities) in 2004.

The rating of firms' environmental behavior is based on the public color-coded ratings system and was proposed by State Bureau of Environmental Protection in 2003 cooperating with World Bank. In the data set for 2004, the batch of 29 pilot cities includes Nanjing, Wuxi, Suzhou, Changzhou, Nantong, Zhenjiang, Xuzhou, Yancheng, Taizhou and Yangzhou in Jiangsu provinces; Hangzhou, Ningbo and Wenzhou in Zhejiang province; Jinan, Yantai and Zibo in Shandong province; Huainan, Huaibei, Tongling Maanshan and Chaohu in Anhui province; Huhehot in Inner Mongolia autonomous region; Jiayuguan in Gansu province; Zhuzhou and Changde in Hunan province; Jiazuo in Henan province, Liuzhou in Guangxi Zhuang autonomous region and 
Chongqing municipality. According to the document of SEPA (2004), the grading system draws on 15 indicators (see Table A1 in Appendix) and the conceptual scheme of the grading system is shown in Figure A1 in Appendix. On the basis of the grading system, firms' environmental performance is divided into five symmetric rating categories, ranging from black (the worst performance) through red, yellow and blue, to green (the best performance). Table 1 summarizes the ranking system criteria for each category. Considering the different levels of economic development and the heterogeneity in stringency of environmental regulation across regions, it is quite possible that some local governments tend to loose evaluation standards. Therefore, we cannot rule out the possibility that green/blue statuses are achieved by weak standards rather than by firms' strong performances.

Table 1 Grading System of Firm Environmental Performance

\begin{tabular}{|c|c|c|}
\hline Color & Performance & Criteria \\
\hline Green & Excellent & $\begin{array}{l}\text { On the basis of blue color, enterprise obtains ISO } 14000 \text { certificate or } \\
\text { passes cleaner production audit. Corporate environmental management } \\
\text { reaches advanced level. }\end{array}$ \\
\hline Blue & Good & $\begin{array}{l}\text { The emission level is lower than relevant national emission standard. } \\
\text { Enterprise has high level corporate environmental management. }\end{array}$ \\
\hline Yellow & Fair & $\begin{array}{l}\text { The emissions on the whole comply with relevant national emission } \\
\text { standard. Emission level exceeding relevant national emission standard or } \\
\text { non-compliance occurs occasionally. }\end{array}$ \\
\hline Red & Poor & $\begin{array}{l}\text { Emissions cannot comply with relevant national emission standard or } \\
\text { more serious pollution accident happens. }\end{array}$ \\
\hline Black & Very Poor & $\begin{array}{l}\text { Emission level greatly exceeds relevant national emission standard and } \\
\text { causes serious environmental impact or the most serious pollution } \\
\text { accident happens. }\end{array}$ \\
\hline
\end{tabular}

Table 2 presents the distribution of firms that participate in environmental ranking system by cities in 2004. In the whole sample, 56.2\% of the sample firms are grouped in Hangzhou, Nanjing, Ningbo and Suzhou, these 4 eastern coastal cities, reflecting the size and situation of regional industrial agglomeration in China.

To maintain confidentiality, the environmental information disclosure system of State Bureau of Environmental Protection only provides information on firms' names, locations and levels of environmental performance. Hence, in order to obtain more firm-level and city-level characteristics, we use firm's name and its location to link the environmental performance dataset to the China Industrial Enterprises Database (2004) and the dataset of China Industrial Yearbook (2005). China Industrial Enterprises Database collects almost all important aspects of a firms' operation covering firms from all business sectors. We use a subset of the database data that contains the industrial firms in our environmental performance data and their detailed firm-level information, including ownership types, industry code, city code, R\&D expenditure, sales, employee education level, asset, number of employment, value of exports, profits and industrial value added and etc. The China environmental statistics yearbook contains information about the air quality of city and the amount of pollution emission of each industry. After matching the data sets, we obtain a sample of 2554 firms from 29 cities. For each firm we have information on firms characteristics such as levels of environmental performance, ownership types, firm size, firm age, industrial code, annual R\&D expenditure, annual profit, annual value of exports, annual sales, total asset value and etc, and city-level variables such as GDP per capita, unemployment rate, population density and market-oriented degree. The definitions and statistical descriptions of all variables used in our analysis are presented in the Appendix Table A3 and Table A4 respectively.

The information on dropped observations is summarized in Table A2. As shown above, the environmental information disclosure system database only provides firms' information on levels 
of environmental performance and their locations; we cannot apply the common data imputation technique to deal with the missing data since we cannot find additional information to impute the missing values of all independent variables of the deleted observations. To check whether there exist sample selection bias or not, we carry out Chi-square significance tests by comparing the matched sample and full sample. Chi-square test of the null hypothesis is that there is no sample selection bias. First, we calculate the Chi-square test statistic only considering the distribution of 5level environmental performance. After calculation, we get $\chi^{2}=0.106$ (critical value of $\chi^{2}=9.488$ with $4(=5-1)$ degree of freedom at the $1 \%$ significant level). Since $\chi^{2}$ statistic is smaller than its critical value, we cannot reject the null hypothesis of no bias. Next, we calculate $\chi^{2}$ statistic by considering the distributions of environmental compliance in each city. Since $\chi^{2}$ statistic $(0.595)$ does not exceeded the critical value for $1 \%$ significant level $(80.15)$ with $112(=28 \times 4)$ degree of freedom we accept the null hypothesis that there is no selection bias.

Table 2 City profiles: all sample (2004)

\begin{tabular}{|c|c|c|c|c|c|c|c|c|c|}
\hline \multirow[b]{2}{*}{ City } & \multicolumn{6}{|c|}{ Rating of Environmental performance } & \multirow{2}{*}{$\begin{array}{c}\text { Population } \\
\text { (10000 persons) }\end{array}$} & \multirow{2}{*}{$\begin{array}{l}\text { GDP/capita } \\
\text { (10000 yuan) }\end{array}$} & \multirow{2}{*}{$\begin{array}{c}\text { Air } \\
\text { quality } \\
\text { index }\end{array}$} \\
\hline & Green & Blue & Yellow & Red & Black & $\begin{array}{r}\text { No. of } \\
\text { firms }\end{array}$ & & & \\
\hline Changde & 2 & 7 & 11 & 2 & 1 & 23 & 601.05 & 1.83 & 0.87 \\
\hline Changzhou & 7 & 23 & 12 & 2 & 0 & 44 & 348.97 & 3.63 & 0.82 \\
\hline Chaohu & 4 & 12 & 14 & 11 & 0 & 41 & 453.96 & 0.89 & 0.85 \\
\hline Chongqing & 0 & 13 & 6 & 4 & 2 & 25 & 1017.57 & 1.33 & 0.66 \\
\hline Hangzhou & 48 & 100 & 192 & 55 & 5 & 400 & 651.68 & 4.91 & 0.80 \\
\hline Huaibei & 6 & 31 & 16 & 3 & 3 & 59 & 209.39 & 1.50 & 0.82 \\
\hline Huainan & 2 & 18 & 33 & 5 & 2 & 60 & 233.58 & 0.98 & 0.85 \\
\hline Huhehot & 13 & 41 & 25 & 7 & 1 & 87 & 214.70 & 3.16 & 0.85 \\
\hline Jiaozuo & 0 & 20 & 5 & 2 & 0 & 27 & 345.50 & 1.48 & 0.64 \\
\hline Jiayuguan & 1 & 6 & 7 & 3 & 0 & 17 & 16.76 & 2.52 & 0.90 \\
\hline Jinan & 10 & 17 & 19 & 4 & 2 & 52 & 590.08 & 3.67 & 0.57 \\
\hline Liuzhou & 13 & 39 & 35 & 7 & 1 & 95 & 210.24 & 1.92 & 0.75 \\
\hline Maanshan & 2 & 18 & 8 & 3 & 1 & 32 & 124.39 & 2.95 & 0.95 \\
\hline Nanjing & 74 & 269 & 208 & 38 & 5 & 594 & 583.60 & 3.55 & 0.81 \\
\hline Nantong & 18 & 35 & 47 & 12 & 4 & 116 & 773.79 & 3.51 & 0.88 \\
\hline Ningbo & 84 & 261 & 116 & 4 & 1 & 466 & 552.69 & 6.04 & 0.92 \\
\hline Suzhou & 140 & 278 & 198 & 19 & 3 & 638 & 598.85 & 6.03 & 0.84 \\
\hline Taizhou & 10 & 46 & 40 & 10 & 4 & 110 & 502.77 & 3.17 & 0.79 \\
\hline Tongling & 10 & 57 & 53 & 13 & 3 & 136 & 71.63 & 2.98 & 0.86 \\
\hline Wenzhou & 8 & 31 & 15 & 0 & 1 & 55 & 746.19 & 4.58 & 0.97 \\
\hline Wuxi & 21 & 77 & 71 & 12 & 3 & 184 & 447.19 & 5.90 & 0.79 \\
\hline Xuzhou & 5 & 23 & 34 & 7 & 4 & 73 & 916.85 & 3.16 & 0.60 \\
\hline Yancheng & 5 & 30 & 20 & 3 & 0 & 58 & 798.28 & 1.59 & 0.67 \\
\hline Yangzhou & 3 & 14 & 31 & 4 & 2 & 54 & 454.29 & 3.22 & 0.82 \\
\hline Yantai & 8 & 16 & 14 & 10 & 6 & 54 & 354.51 & 2.32 & 0.99 \\
\hline Zhenjiang & 24 & 93 & 40 & 5 & 4 & 166 & 267.21 & 3.50 & 0.73 \\
\hline Zhuzhou & 1 & 18 & 11 & 4 & 1 & 35 & 370.93 & 2.48 & 0.53 \\
\hline Zibo & 6 & 5 & 5 & 12 & 0 & 28 & 450.51 & 2.40 & 0.81 \\
\hline Total & 525 & 1598 & 1286 & 261 & 59 & 3729 & & & \\
\hline
\end{tabular}

Table 3 summarizes the distribution of firms. We define the levels of compliance as overcompliance, compliance and non-compliance according to the criteria of ranking as shown in Table 1. Category green and blue are combined to obtain over-compliance and it represents $56.1 \%$ of 
firms in the data. The firms in these two categories have exceeded the environmental requirements and claimed to have established high-level environmental management in their organization. Category yellow is defined as compliance (32.1\% of firms) and includes firms that consistently observe the environmental regulations or usually comply with emission standards, though they sometimes fail in specific points. Categories red and black include firms that usually fail to obey environmental regulations and even cause the pollution accidents. Categories red and black are merged to obtain non-compliance since each of them accounts for a small percentage of total firms.

Table 3 Environmental performance and firms' distribution

\begin{tabular}{|c|c|c|c|c|c|}
\hline \multirow{2}{*}{$\begin{array}{l}\text { Environmental compliance } \\
\text { Color }\end{array}$} & \multicolumn{2}{|c|}{ Over-compliance } & \multirow{2}{*}{$\frac{\text { Compliance }}{\text { Yellow }}$} & \multicolumn{2}{|c|}{ Non-compliance } \\
\hline & Green & Blue & & Red & Black \\
\hline No. of firms & 362 & 1072 & 820 & 253 & 47 \\
\hline Percent & 14.2 & 42.0 & 32.1 & 9.9 & 1.8 \\
\hline Cum. & 14.2 & 56.1 & 88.3 & 98.2 & 100.0 \\
\hline
\end{tabular}

\subsection{Empirical methodology and variables}

To measure the actual outcome from internal and external effects we use data on the grading of firms' environmental performances. Besides a variety of firm- and industry- characteristics, we also include a number of other control variables designed to capture characteristics of the location of firm that could influence the level of regulatory activity it faces.

The dependent variable environmental compliance $\mathrm{C}_{\mathrm{ji}}$ is a function of firm- and city-PEOPLE characteristics, as well as INDUSTRY and LOCATION variables.

$$
\mathrm{C}_{\mathrm{ji}}=\mathrm{f}\left(\text { FPEOPLE }_{\mathrm{ji}}, \mathrm{FX}_{\mathrm{ji}}, \text { CPEOPLE }_{\mathrm{j}}, \mathrm{CX}_{\mathrm{j}}, \operatorname{INDUSTRY}_{\mathrm{ji}}, \operatorname{LOCATION}_{\mathrm{j}}\right)
$$

Following previous research studies, in addition to human capital, some other determinants that may have effects on environmental performance are also included in the estimation model as explanatory variables. We estimate the following model,

$$
\operatorname{Pr}\left(\text { Compliance }=\mathrm{m} \mid \mathrm{x}_{\mathrm{i}}\right)=\mathrm{F}\left(\tau_{\mathrm{m}}-\mathrm{X} \Phi\right)-\mathrm{F}\left(\tau_{\mathrm{m}-1}-\mathrm{X} \Phi\right)
$$

and X $\Phi+\varepsilon=\sum \alpha_{\mathrm{h}}$ FPEOPLE $_{\mathrm{jih}}+\beta_{1}$ Exports $+\beta_{2} \mathrm{RD}_{\mathrm{ji}}+\beta_{3} \mathrm{ROA}_{\mathrm{ji}}+\beta_{4} \mathrm{SIZE}_{\mathrm{ji}}+\sum \rho_{\mathrm{n}}$ OWNERSHIP $_{\mathrm{jin}}$

$$
\begin{aligned}
& +\sum \gamma_{\mathrm{h}} \text { CPEOPLE }_{\mathrm{jh}}+\beta_{5} \text { AIRquality }_{\mathrm{j}}+\sum \varphi_{\mathrm{h}} \text { CPEOPLE }_{\mathrm{jh}} \times \text { AIRquality }_{\mathrm{j}}+\beta_{6} \mathrm{UNEMP} \beta_{7} \text { POPden }_{\mathrm{j}} \\
+ & \beta_{8} \text { Market }_{\mathrm{j}}+\beta_{9} \text { GDPcap }_{\mathrm{j}}+\beta_{10} \mathrm{INTso}_{\mathrm{s}}+\beta_{11} \mathrm{INTwater}_{\mathrm{s}}+\beta_{12} \mathrm{INTsoot}_{\mathrm{s}}+\beta_{13} \mathrm{WEST}+\beta_{14} \text { EAST } \varepsilon_{\mathrm{ji}}
\end{aligned}
$$

where $\mathrm{F}$ is the cumulative distribution function of error term $\varepsilon$ and $\mathrm{F}$ is normal with $\operatorname{VAR}(\varepsilon)=1 . \tau_{\mathrm{m}}$ and $\tau_{\mathrm{m}-1}$ are two cutpoints (thresholds) and two cutpoints leads to three levels of firms' environmental performance: over-compliance, compliance and non-compliance. The ordered variable $\left(\mathrm{C}_{\mathrm{i}}\right)$ is our indicator for environmental performance. FPEOPLE is a vector of share of employment with different education levels for firm: share of employment with college education and above (FCOLLEGE $\mathrm{j}_{\mathrm{ji}}$ ), share of employment with senior high school education (FSENIOR $\mathrm{ji}_{\mathrm{ji}}$ ) and share of employment with primary school education and below (FPRIMARY ${ }_{\mathrm{ji}}$ ). CPEOPLE is a vector of ratios of population with different education levels in a city including the share of population with college education and above $\left(\mathrm{CCOLLEGE}_{\mathrm{j}}\right)$, share of population with senior high school education $\left(\mathrm{CSENIOR}_{\mathrm{j}}\right.$ ) and share of population with primary school education and below $\left(\right.$ CPRIMARY $_{\mathrm{j}}$ ). In both cases, the reference group in our study is population with junior high school education. 
First, let us review the variables of PEOPLE characteristics, those influencing the marginal benefits and marginal cost from pollution abatement at a particular firm. On the marginal cost side, we have the percentage of employees with different education levels within the firm (FCOLLEGE ${ }_{\mathrm{ji}}$, FSENIOR $_{\mathrm{ji}}$ and FPRIMARY $\mathrm{ji}_{\mathrm{ji}}$. On the marginal benefit side, we also have the percentage of the population with different education levels in the city $\left(\mathrm{CCOLLEGE}_{\mathrm{j}}, \mathrm{CSENIOR}_{\mathrm{j}}\right.$ and $\mathrm{CPRIMARY}_{\mathrm{j}}$, $\sigma_{\text {hq }}$ in Eq (2)), representing the sensitivities to environmental quality of different educational groups. We would expect to find positive signs for the coefficients in the high human capital levels of both firm and city.

Next we define the firm-level explanatory variables that may affect a firm's environmental performance. Research and development expenditure (RD), a proxy for the innovation within firms, will often lead to the improvements to the firm's production process, might resulting in less need for energy per unit output. Thus, we might expect innovation expenditure to reduce a firm's emission of pollutants. Firm size (SIZE) is measured by the natural logarithm form of employment. Cole et al. (2008a) investigate the role played by foreign direct investment on firms' environmental performance and find that the size of firm is negatively related to its energy intensity and larger sized firms tend to have better environmental performance. We therefore expect a positive relationship between firm's size and its environmental performance. Age (AGE) is defined as the number of years from the year of their registration to year 2004, given the likelihood that newer firms may use more modern, cleaner technology to reduce the emissions (Cole et al., 2008a). A measure of the share of sales of each firm that is exported (Export) given the possibility that exporters may be cleaner in order to serve export market in the developed world where consumers are typical environmentally conscious. A proxy for firm's financial performance is ROA given that firms with better financial performance often have better environmental performance. ${ }^{1}$

We also include the firm-level ownership dummies in our empirical model. The 2004 survey data of China Industrial enterprises database defined six types of firm ownership. In particular, they are state-owned enterprises (SOE), foreign-owned enterprises (FDI), privately-owned enterprises (PRIVATE), public-listed companies (PUBLIC), collectives (COLLECTIVE), and non-stateowned limited companies (LIMITED). These six types of ownership are mutually exclusive. SOEs include domestic SOEs, alliances of SOEs, and unlisted state-owned limited companies. Foreignowned enterprises include joint ventures with Hong Kong, Macau, Taiwan (HMT) and other foreign investors. They also include HMT wholly-owned companies, HMT shareholding companies, wholly foreign owned companies, and foreign shareholding companies. Privatelyowned firms include private limited companies, private shareholding companies, proprietorships and partnerships. Public-listed companies are domestic public-listed companies. Collectives include companies that are registered as domestic collectives or domestic alliances of collectives. To compare the different environmental performances of foreign-owned enterprises, we make a separation of HMT related firms (including HMT wholly-owned firms and HMT shareholding firms) and other foreign related firms (including wholly foreign owned firms and foreign shareholding firms).

The control variables of industrial characteristics include proxies for industrial dirtiness (INTso2, INTwater and INTsoot calculated as industrial emissions scaled by industrial value added) given the possibility that the dirtier the industry a firm included in, the worse environmental performance it shows.

Our explanatory variables of city and regional characteristics include AIRquality Unemployment, POPdensity, Market, EAST and WEST. Using socioeconomic characteristics to

\footnotetext{
${ }^{1}$ As shown by Wang and Wheeler (2005), the cost of abatement technology is usually fixed, but pollution and thus government fines increases with output, so the relative cost of environmental compliance decreases with output.
} 
identify the effect of community pressure may pick up any number of unobserved determinants of formal and informal regulatory pressures. We use the local environmental conditions, measured by air quality (AIRquality) as a proxy for social effort made to maintain or improve the environmental quality given the possibility that the more stringent environmental regulations might be imposed to maintain the better environmental condition. The proxies for local protectionism include Unemployment and Market. The unemployment rate might affect local pollution regulations for two reasons. First, a high unemployment rate in a region might attract more attention from the local authorities and force them to devote more resources to dealing with unemployment hence devoting fewer resources to pollution control. Second, communities in a region may tolerate the existence of a polluting plant nearby if it provides employment. Such an effect is more likely to occur in cities with a high level of unemployment. Both arguments suggest that a region with a high unemployment rate will tend to have lax environmental regulations and tolerate non-compliance with environmental regulations. Market is obtained from the NERI (National Economic Research Institute) Index of Marketization of China's Provinces 2006 Report to measure the effort of local government to reduce local protectionism. A higher value indicates lower entry barrier to the local market and thus smaller local protection. We expect a city with higher Marketization index is associated with better environmental performance of the firm located in that city. Population density (POPdensity) may affect firms' environmental behaviors through two ways. On the one hand, a densely populated area may imply there are more people adversely affected by pollution and hence opposition to such plants may be greater. Conversely, a pollution intensive plant may be less 'visible' in a densely populated, urban area and hence may escape the attentions of the local population (Cole et al., 2005). EAST and WEST are regional dummies to capture the regional heterogeneity while central part of China works as the reference group.

Finally, we add interactions between the air quality and the share of population in each education group to see whether the coefficient on the interaction terms differ across different educational groups, which also indirectly reflecting the different susceptibilities from different educational group on environmental conditions.

\subsection{Potential problem and instruments selection}

Following the instrumental-variables strategy of Fisman and Svensson (2007), we use industrylocation average share of college and above educated employees (ICOLLEGE) as an instrument al variable for FCOLLEGE. Our identifying assumption to deal with this problem is that FCOLLEGE $_{\mathrm{ji}}$ can be decomposed into two terms, one industry-specific, and the other particular to the firm: FCOLLEGE $_{\mathrm{jsi}}=$ Fcollege $_{\mathrm{jsi}}+$ ICOLLEGE $_{\mathrm{j} \mathrm{s}}$. Here, ICOLLEGE Is $_{\mathrm{s}}$ denotes the (average) share of college and above educated employees common to location $\mathrm{j}$ and industry $\mathrm{s}$, which in turn is a function of the underlying characteristics inherent to that particular industry location, while Fcollege $_{\mathrm{ji}}$ denotes the specific component. We assume that the industry-specific part of human capital is determined by industry-specific components, we assume that ICOLLEGE $_{j}$ is exogenous to the firm, and hence uncorrelated with the error term $\varepsilon$. If this assumption is valid, we may use ICOLLEGE $_{\mathrm{js}}$ to instrument for FCOLLEGE $_{\mathrm{jsi}}$, since CORR(ICOLLEGE $\left.{ }_{\mathrm{js}}, \varepsilon\right)=0$. In such a specification, using industry-location averages as an instrument for firm-level FCOLLEGE jsi $_{\text {gets }}$ rid of the biases resulting from omitted variables that are correlated with FCOLLEGE $_{\mathrm{jsi}}$ at the firm. In our case, the industry-location averages we use should serve to mitigate the effects of measurement error which is a common concern when using micro-level data, since we generally think of these errors as being largely idiosyncratic to the firm, and hence uncorrelated with the average human capital level. We then define

$$
\text { ICOLLEGE }=\frac{\sum_{\mathrm{i}=1}^{\mathrm{n}} \text { Number of employee with college and above education }_{\mathrm{jsi}}}{\sum_{\mathrm{i}=1}^{\mathrm{n}} \text { Number } \text { of employee }}
$$


where $\mathrm{n}$ is the number of firms in industry s, city j. ${ }^{2}$ The range of ICOLLEGE is $[0,1]$.

Another concern of this analysis is the potential problem for reverse causality due to selfselection of external human capital. Higher educated people could move to cleaner cities because they are more sensitive to environmental quality. Due to the existence of rigid "Hukou" system, labor in China is not as mobile as that in other countries in the world, whereas China still has witnessed tremendous internal labor migration since the reform of "Hukou" system was implemented. Thus, we cannot rule out this endogenous problem. To address this potential endogeneity, we introduce average number of books per person in public libraries (BOOK) and number of universities and colleges (UNIVERSITY) in each city as two instrumental variables for CCOLLEGE. These two instruments can be used as proxies for human capital stock of cities but are intuitively likely to be uncorrelated with environmental compliance.

Besides the possible endogeneity caused by human capital, another potential problem arises if the degree of environmental compliance is the joint result of government regulation and firm initiatives as shown by Yang and Yao (2012) and Wang and Wheeler (2005). For example, if a firm violates an environmental regulation or causes an environmental accident, the firm not only has to pay fines and penalties, but may suffer from a loss of trust and reputation or a boycott of goods. Such risks have negative effects on the evaluation of a firm's future profits. On the other hand, a firm that actively addresses environmental issues might gain positive reputation among some stakeholders and may influence them to expect that the firm will succeed in reducing environmental risks and production costs in the long term. As a result, better financial performance could be a result of better environmental performance. By using the same strategy of instrument selection, we take industrial-location average ROA as instrumental variable for firm-level financial performance. Industrial-location average of ROA is defined as $\operatorname{IROA}_{\mathrm{js}}=\frac{\sum_{\mathrm{i}=1}^{\mathrm{n}} \text { Profit }_{\mathrm{jsi}}}{\sum_{\mathrm{i}=1}^{\mathrm{n}} \text { Asset }_{\mathrm{jsi}}}$, where $\mathrm{n}$ is the number of firms in industry s, city j. ${ }^{3}$

\section{Estimation Results}

\subsection{Case of the full sample}

Table 4 presents the estimated coefficients and their associated standard errors (SEs) of the ordered probit model as well as conditional mixed process model (ordered probit model with instrument adjustment). As a test of identification, besides the ICOLLEGE and IROA, we include two industry-location averages as additional instrument variables. Since the intangible assets (knowledge and skills) are embodied in the firm's employees and the main factor of it is human capital, the first variable we include is percentage of total assets represented by intangible assets intensity (INTANG) calculated as the ratio of intangible assets to total assets. The second variable is fixed assets divided by total sales (FIXSALE) which aims to measure a firms' efficiency in terms of amount of fixed asset needed to produce a unit of sale. This variable should affect (negatively) the financial performance, but not, at least, intuitively the environmental performance of firms. In regression (2), Table 4, we add six instrumental variables in the ordered-probit specification. The coefficients on FCOLLEGE, CCOLLEGE and ROA become larger in absolute values, while the extents of all instrumental controls enter insignificantly. In regression (3), we instead add these six control variables as instruments. To the extent that our instrumental variables have no direct effect on firms' environmental performance as suggest in (regression (2)) and since they influence to what extent firms are through FCOLLEGE, CCOLLEGE and ROA, they are valid instruments.

\footnotetext{
${ }^{2}$ ICOLLEGE $_{\mathrm{js}}$ is computed from the National Bureau of Statistics (NSB) Enterprise Database since our sample is not big enough for computing the industry average level of human capital level.

${ }^{3}$ IROA $_{\mathrm{js}}$ is computed from the National Bureau of Statistics (NSB) Enterprise Database.
} 
Adding these additional instruments has the advantage that the model is now over-identified and that the validity of the instruments can be tested. We present some tests results to indicate the quality and validity of the instrument variables used. The instruments perform well. The F-statistics of their joint significance are $77.60,57.70$ and 37.76 respectively and are highly significant. Moreover, we conduct over-identification test by a Hansen's J statistic. Our instrumental variables are all significantly correlated with the instrumented variables. As the p-value of Hansen's J statistic is 0.574, we cannot reject the joint null hypothesis that the instruments are valid instruments. These tests provide support for the validity of our instruments.

Table 4 Estimates for ordered probit environmental compliance model (full sample)

\begin{tabular}{|c|c|c|c|c|c|c|}
\hline \multirow{2}{*}{ Variable } & \multicolumn{2}{|c|}{ OPROBIT (1) } & \multicolumn{2}{|c|}{ OPROBIT (2) } & \multicolumn{2}{|c|}{ IV OPROBIT (3) } \\
\hline & $\mathrm{COEF}$ & $\mathrm{SE}$ & $\mathrm{COEF}$ & $\mathrm{SE}$ & $\mathrm{COEF}$ & $\mathrm{SE}$ \\
\hline FCOLLEGE & $1.761^{* * *}$ & 0.627 & $1.819^{* * *}$ & 0.636 & $1.844^{* * *}$ & 0.649 \\
\hline FSENIOR & $1.624^{*}$ & 0.868 & $1.634^{*}$ & 0.979 & $1.674^{*}$ & 0.985 \\
\hline FPRIMARY & $-1.594^{* *}$ & 0.715 & $-1.609^{* * *}$ & 0.638 & $-1.645^{* *}$ & 0.758 \\
\hline CCOLLEGE & $1.723^{* * *}$ & 0.692 & $1.900^{* * *}$ & 0.531 & $2.027^{* * *}$ & 0.596 \\
\hline CSENIOR & 0.828 & 0.579 & 0.880 & 0.778 & 0.863 & 0.599 \\
\hline CPRIMARY & $-0.941^{* *}$ & 1.365 & $-1.017^{* *}$ & 0.433 & $-1.038^{* *}$ & 0.465 \\
\hline AIRCOLLEGE & $1.295^{* * *}$ & 0.445 & $1.296^{* *}$ & 0.535 & $1.295^{* *}$ & 0.553 \\
\hline AIRSENIOR & 1.377 & 0.924 & 1.438 & 1.006 & 1.423 & 1.039 \\
\hline AIRPRIMARY & $-0.574^{* *}$ & 0.243 & $-0.586^{* *}$ & 0.277 & $-0.580^{* *}$ & 0.248 \\
\hline Export & $0.186^{* *}$ & 0.091 & $0.196^{* *}$ & 0.099 & $0.205^{* *}$ & 0.099 \\
\hline $\mathrm{RD}$ & $1.125^{* * *}$ & 0.391 & $1.095^{* * *}$ & 0.388 & $1.106^{* * *}$ & 0.390 \\
\hline SIZE & 0.032 & 0.027 & 0.035 & 0.023 & 0.055 & 0.027 \\
\hline AGE & -0.013 & 0.027 & -0.011 & 0.021 & -0.014 & 0.027 \\
\hline ROA & $0.534^{* * *}$ & 0.240 & $0.538^{* *}$ & 0.239 & $0.543^{* * *}$ & 0.208 \\
\hline FDI & $0.340^{* * *}$ & 0.121 & $0.340^{* * *}$ & 0.122 & $0.341^{* * *}$ & 0.120 \\
\hline Collective & -0.071 & 0.140 & -0.110 & 0.137 & -0.109 & 0.140 \\
\hline HMT & 0.069 & 0.121 & 0.069 & 0.140 & 0.066 & 0.129 \\
\hline Limited & -0.031 & 0.107 & -0.033 & 0.108 & -0.032 & 0.107 \\
\hline Private & 0.016 & 0.063 & 0.015 & 0.067 & 0.021 & 0.104 \\
\hline SOE & -0.011 & 0.034 & -0.012 & 0.034 & -0.021 & 0.032 \\
\hline AIRquality & $1.722^{* *}$ & 0.742 & $1.800^{* *}$ & 0.776 & $1.755^{* *}$ & 0.787 \\
\hline UNEMP & $-2.114^{* * *}$ & 0.436 & $-2.053^{* * *}$ & 0.341 & $-2.107^{* * *}$ & 0.392 \\
\hline INTso 2 & $-0.276^{* *}$ & 0.115 & $-0.283^{* *}$ & 0.133 & $-0.274^{* *}$ & 0.129 \\
\hline INTwater & -0.059 & 0.071 & -0.055 & 0.071 & -0.054 & 0.071 \\
\hline INTsoot & $-0.261^{* *}$ & 0.118 & $-0.263^{* *}$ & 0.120 & $-0.268^{* *}$ & 0.118 \\
\hline MARKET & -0.166 & 0.192 & -0.155 & 0.172 & -0.164 & 0.190 \\
\hline GDPcap & $0.015^{* * *}$ & 0.003 & $0.013^{* * *}$ & 0.003 & $0.015^{* * *}$ & 0.003 \\
\hline POPdensity & 0.185 & 0.153 & 0.192 & 0.154 & 0.194 & 0.157 \\
\hline WEST & $-1.047^{* *}$ & 0.528 & $-1.040^{* *}$ & 0.512 & $-1.062^{* *}$ & 0.481 \\
\hline EAST & 0.584 & 0.453 & 0.573 & 0.424 & 0.599 & 0.474 \\
\hline ICOLLEGE & & & 0.084 & 0.384 & & \\
\hline IINTANG & & & 0.386 & 1.061 & & \\
\hline BOOK & & & 0.072 & 0.080 & & \\
\hline UNIVERSITY & & & 0.098 & 0.147 & & \\
\hline IROA & & & 1.263 & 1.025 & & \\
\hline IFIXSALE & & & -0.015 & 0.028 & & \\
\hline
\end{tabular}


Table 4 Continued

\begin{tabular}{|c|c|c|c|c|c|c|c|}
\hline \multirow{2}{*}{ Variable } & & \multicolumn{2}{|c|}{ OPROBIT (1) } & \multicolumn{2}{|c|}{ OPROBIT (2) } & \multicolumn{2}{|c|}{ IV OPROBIT (3) } \\
\hline & & COEF & $\mathrm{SE}$ & COEF & $\mathrm{SE}$ & COEF & SE \\
\hline \multicolumn{8}{|c|}{ Instrumentation step } \\
\hline \multicolumn{8}{|c|}{ FCOLLEGE } \\
\hline & IINTANG & & & & & $0.130^{*}$ & 0.074 \\
\hline \multicolumn{8}{|l|}{ CCOLLEGE } \\
\hline & $\mathrm{BOOK}$ & & & & & $0.025^{* * *}$ & 0.008 \\
\hline & UNIVERSITY & & & & & $0.002^{* * *}$ & 0.0006 \\
\hline \multicolumn{8}{|l|}{ ROA } \\
\hline & $\begin{array}{l}\text { IRUA } \\
\text { IFIXSALE }\end{array}$ & & & & & $\begin{array}{r}0.636 \\
-0.041^{* *}\end{array}$ & $\begin{array}{l}0.253 \\
0.022\end{array}$ \\
\hline \multicolumn{2}{|c|}{ Log-likelihood } & -1856.653 & & -1850.212 & & 2187.235 & \\
\hline \multicolumn{2}{|l|}{ LR chi 2} & 493.38 & & 495.13 & & & \\
\hline \multicolumn{2}{|l|}{ Prob > chi2 } & 0.000 & & 0.000 & & 0.000 & \\
\hline \multicolumn{2}{|l|}{ Pseudo- $\mathrm{R}^{2}$} & 0.197 & & 0.199 & & & \\
\hline \multicolumn{2}{|c|}{ Wald Chi2 } & & & & & 612.30 & \\
\hline \multicolumn{2}{|c|}{$\begin{array}{l}\text { F-test of instruments } \\
\text { (in FCOLLEGE regression) }\end{array}$} & & & & & 77.60 & $\{0.000\}$ \\
\hline \multicolumn{2}{|c|}{$\begin{array}{l}\text { F-test of instruments } \\
\text { (in CCOLLEGE regression) }\end{array}$} & & & & & 57.70 & $\{0.000\}$ \\
\hline \multicolumn{2}{|c|}{ F-test of instruments } & & & & & 37.76 & $\{0.000\}$ \\
\hline \multicolumn{2}{|c|}{ Hansen J-statistics } & & & & & 1.970 & $\{0.574\}$ \\
\hline \multicolumn{2}{|c|}{ Observations } & 2554 & & 2554 & & 2554 & \\
\hline
\end{tabular}

${ }^{*}$ Significant at $10 \%$ level; ${ }^{* *}$ Significant at $5 \%$ level $;{ }^{* * *}$ Significant at $1 \%$ level.

Heteroskedasticity-robust standard errors reported.

All regressions allow for clustering by location-industry.

F-test on instruments is the test statistics on the F-test of the joint significance of the instruments (ICOLLEGE, IROA, BOOK, UNIVERSITY, IINTANG and IFIXSALE), with p-values in braces. Hansen $\mathrm{J}$-statistics is the test statistic on the overidentification test of instruments, with p-values in braces.

To account for the endogenous problems, a three-equation instrumental variables version of the ordered probit model is estimated, utilizing the CMP package for STATA 12.1.

Most of the coefficient show expected signs and high significance. The first point to note is that, high human capital contributes to firms' environmental performance both from the interior and the exterior. As it can be seen from Table 4, FCOLLEGE and CCOLLEGE are positively associated with firms' environmental performance, implying that a firm with more college (and above) educated employees is more likely to better comply with environmental regulations and a firm located in a city with more college (and above) population tend to have better environmental performance. Our estimates of low human capital variables (FPRIMARY and CPRIMARY) are consistently negatively associated with firms' environmental compliance. For the senior school educated (FSENIOR and CSENIOR), it has significantly positive internal effect to push firms to do better compliance while its external effect is insignificant. Comparing the differences across education groups in their susceptibilities to environmental condition, our interaction terms show that greater sensitivities associated with better compliance of firms located in the city with higher share of college (and above) educated population and lower share of primary school educated population, reflecting that regulatory pressure could differ across cities due to different educational degree of population. 
With regard to the variables of firm characteristics, results in Table 4 present that, R\&D expenditure per unit of sales (RD) is consistently positive, suggesting that firms that invest in innovation are more likely to observe environmental regulations. Value of exports per unit of sales (Export), one of proxies for firms' international linkage, is found to be positive determinants of firms' environmental performance and the effect is significant. The positive coefficient on Export is in line with Christmann and Taylor (2001), who show the evidence that export-oriented Chinese firms are more likely to adopt ISO 14001 certification to control for emissions. A similar finding has been reported in (Galdeano-Gómez, 2010), where it is argued that an export-oriented firm has a better environmental performance in Spanish food industry. The ownership dummies show that, consistent with the results of a positive foreign ownership effect from the most empirical literature, being a foreign firm or foreign related firm increase the probability of compliance with environmental regulations. In terms of other type of ownership, none are found to be statistically significant. Finally, return on assets (ROA) which is instrumented by industrylocation IROA is consistently positive and significant. It implies that firms with better financial performance tend to more likely to have better environmental performance.

Turning to the industrial characteristics variables, the pollution intensive variables suggest that firms in pollution intensive sectors are more likely to violate $\mathrm{SO}_{2}$-related regulations and SOOT-related regulations although they do not perform significantly worse in polluted water related compliance. As Wang and Wheeler (2005) argue that China's water concentration standards are more stringent than its air concentration standards and water emission is targeted by more frequently inspections which induces firms to compliance. On the other hand, the abatement technology of industrial waste water is a relative common practice in some pollution intensive sectors, which induces firms to comply with the standards of acceptable compliance.

In terms of city control variables, we have the following observations. First, firms located in cities with good air quality (AIRquality) are significantly less likely to violate environmental regulations. Firms in cities with higher unemployment ratio (UNEMP) is significant more likely to be non-compliance. The local government may face larger pressure from the existence of high unemployment and tend to have relaxed the environmental. This finding supports the argument in Cole et al. (2008b) that a region with a high unemployment rate may make the local government tolerate the existence of a polluting plant nearby if it provides employment. Finally, our regional variables show that, compared to the reference group (firms located in central part of China), being located in the west increases the probability of observing a non-compliance outcome, whereas being located in the east is insignificant.

\subsection{Case of Clean and Dirty industrial sectors}

To gauge the relationship between dirtiness of an industry and its environmental performance, we divide our sample into six subsets of dirty and relatively clean industrial sectors with respect to polluted water intensive sectors, $\mathrm{SO}_{2}$ intensive sectors and soot intensive sectors. Following the classification criterion for defining industries as pollution-intensive industries suggested by (Mani and Wheeler, 1998), we rank the industrial sectors on actual emission intensity (emission per unit of industrial value-added) by using the data of 2004 Environmental Statistics Yearbook for conventional water pollutants, $\mathrm{SO}_{2}$ and soot emissions and 2004 Industrial Statistics Yearbook for industrial value added of each sector. By considering the magnitude of sectoral pollution intensities simultaneously, we pick up the first 6 dirtiest polluted water-intensive sectors, the first 13 dirtiest $\mathrm{SO}_{2}$-intensive sectors and the first 5 dirtiest soot-intensive sectors as the dirtiest industrial sectors. The rest are considered as relative clean sectors (Table A5).

Table 5 reports the results in the case of clean and dirty industries. Our estimation is robust since the sign and significance of the coefficients of three pollutants are almost similar to those in the case of full example in Table 4. The Hansen's $\mathbf{J}$ test results of overidentifying restrictions 
reject the exogeneity assumption for the sub-sample of water-related and soot-related clean industries, but fail to reject it for other sub-samples. In either case, the test results are only suggestive due to potentially limited power of the test. In the end, exogeneity always needs to be assumed and, we see no reason against exogeneity of our instruments.

One difference between the full sample and dirty and clean industrial sectors is that the internal effect of high human capital (FCOLLEGE) is insignificant in clean sectors of category $\mathrm{SO}_{2}$ and soot. Internal human capital plays an important role in environmental performance of firms in dirty industries. For clean industries, the impact of human capital on environmental compliance is mainly explained by the external effect. It is possible that those clean sectors generate considerably less industrial $\mathrm{SO}_{2}$ and soot emissions than the relative dirty sectors. In this case, high human capital may not play a notable role in pollution abatement. Besides, we can observe that in those $\mathrm{SO}_{2-}$ and soot-related dirty sectors, firms with international linkage via foreign ownership or export-oriented exhibit better compliance with environmental regulatory standards than firms with no international linkage. 
Table 5 Estimates for IV-ordered probit model (clean and dirty industries)

\begin{tabular}{|c|c|c|c|c|c|c|c|c|c|c|c|c|}
\hline \multirow{3}{*}{ Variables } & \multicolumn{4}{|c|}{ WATER } & \multicolumn{4}{|c|}{$\mathrm{SO}_{2}$} & \multicolumn{4}{|c|}{ SOOT } \\
\hline & \multicolumn{2}{|c|}{ Dirty } & \multicolumn{2}{|c|}{ Clean } & \multicolumn{2}{|c|}{ Dirty } & \multicolumn{2}{|c|}{ Clean } & \multicolumn{2}{|c|}{ Dirty } & \multicolumn{2}{|c|}{ Clean } \\
\hline & $\mathrm{COEF}$ & $\mathrm{SE}$ & COEF & $\mathrm{SE}$ & COEF & $\mathrm{SE}$ & COEF & $\mathrm{SE}$ & $\mathrm{COEF}$ & $\mathrm{SE}$ & COEF & $\mathrm{SE}$ \\
\hline FCOLLEGE & $1.691^{* * *}$ & 0.509 & $1.051^{*}$ & 0.629 & $1.464^{* *}$ & 0.618 & 1.744 & 1.112 & $2.907^{* * *}$ & 0.878 & 2.118 & 1.375 \\
\hline FSENIOR & $1.730^{* *}$ & 0.983 & $0.568^{*}$ & 0.342 & 0.286 & 0.192 & 0.306 & 0.251 & 0.500 & 0.318 & 0.287 & 0.263 \\
\hline FPRIMARY & $-0.439^{*}$ & 0.199 & $-1.629^{* *}$ & 0.657 & $-1.124^{* *}$ & 0.504 & $-1.130^{* *}$ & 0.533 & $-0.503^{*}$ & 0.301 & $-1.330^{*}$ & 0.747 \\
\hline CCOLLEGE & $0.787^{* * *}$ & 0.623 & $1.027^{* *}$ & 0.450 & $1.640^{* *}$ & 0.867 & $1.698^{* * *}$ & 0.326 & $1.355^{* * *}$ & 1.497 & $1.529^{* * *}$ & 0.573 \\
\hline CSENIOR & 1.450 & 1.421 & 1.614 & 1.681 & 1.465 & 1.423 & 1.592 & 1.294 & 1.431 & 1.154 & 1.245 & 1.020 \\
\hline CPRIMARY & $-0.937^{* *}$ & 0.386 & $-1.200^{* *}$ & 0.476 & $-0.562^{* *}$ & 0.254 & $-0.712^{*}$ & 0.398 & $-0.821^{* *}$ & 0.417 & $-0.726^{* *}$ & 0.361 \\
\hline AIRCOLLEGE & $1.183^{* *}$ & 0.477 & $1.520^{* *}$ & 0.613 & $1.335^{* *}$ & 0.578 & $1.437^{* *}$ & 0.591 & $1.563^{* *}$ & 0.588 & $1.897^{* *}$ & 0.781 \\
\hline AIRSENIOR & 1.366 & 1.339 & 0.622 & 0.506 & 1.942 & 1.867 & 2.112 & 1.371 & 1.186 & 0.775 & 0.266 & 0.182 \\
\hline AIRPRIMARY & $-0.617^{* *}$ & 0.305 & $-1.282^{* *}$ & 0.509 & $-0.514^{* *}$ & 0.236 & $-0.721^{*}$ & 0.410 & $-0.425^{*}$ & 0.230 & $-0.676^{* *}$ & 0.336 \\
\hline Export & $0.679^{* * *}$ & 0.261 & $0.484^{* * *}$ & 0.126 & $0.892^{* *}$ & 0.361 & 0.337 & 0.215 & $0.461^{* *}$ & 0.231 & 0.278 & 0.193 \\
\hline RD & $1.308^{* * *}$ & 0.505 & $1.296^{* * *}$ & 0.431 & $0.991^{* * *}$ & 0.274 & $1.306^{* * *}$ & 0.507 & $1.226^{* *}$ & 0.619 & $1.525^{* * *}$ & 0.442 \\
\hline SIZE & 0.056 & 0.042 & 0.038 & 0.032 & 0.019 & 0.038 & $0.067^{*}$ & 0.033 & 0.014 & 0.067 & $0.065^{* *}$ & 0.027 \\
\hline AGE & -0.017 & 0.041 & -0.018 & 0.049 & -0.022 & 0.041 & -0.014 & 0.041 & -0.044 & 0.079 & 0.026 & 0.029 \\
\hline ROA & $1.587^{* *}$ & 0.718 & $0.387^{*}$ & 0.226 & $1.691^{* * *}$ & 0.587 & $0.410^{* *}$ & 0.207 & $1.546^{*}$ & 0.840 & $0.855^{* * *}$ & 0.314 \\
\hline FDI & $0.704^{* * *}$ & 0.203 & $0.162^{* *}$ & 0.081 & $0.525^{* * *}$ & 0.182 & 0.267 & 0.168 & $0.285^{* *}$ & 0.114 & 0.440 & 0.277 \\
\hline Collective & -0.130 & 0.195 & -0.236 & 0.184 & -0.107 & 0.191 & -0.113 & 0.204 & -0.109 & 0.323 & -0.063 & 0.144 \\
\hline HMT & 0.101 & 0.193 & 0.138 & 0.154 & 0.059 & 0.167 & -0.064 & 0.167 & -0.267 & 0.287 & 0.117 & 0.121 \\
\hline Limited & -0.094 & 0.167 & -0.119 & 0.137 & 0.064 & 0.179 & -0.132 & 0.156 & -0.171 & 0.238 & 0.033 & 0.125 \\
\hline Private & 0.157 & 0.169 & -0.054 & 0.133 & 0.261 & 0.149 & -0.097 & 0.133 & -0.122 & 0.257 & 0.124 & 0.119 \\
\hline SOE & -0.041 & 0.087 & -0.160 & 0.160 & -0.169 & 0.154 & -0.189 & 0.142 & 0.208 & 0.305 & -0.053 & 0.152 \\
\hline AIRquality & $2.658^{* *}$ & 1.136 & 1.204 & 0.747 & $2.863^{* * *}$ & 0.786 & $3.787^{* *}$ & 1.565 & $2.906^{* *}$ & 1.378 & $2.674^{* *}$ & 1.151 \\
\hline UNEMP & $-2.734^{* * *}$ & 0.795 & $-1.920^{* * *}$ & 0.475 & $-2.905^{* * *}$ & 0.499 & $-1.832^{* * *}$ & 0.481 & $-3.651^{* * *}$ & 1.055 & $-2.113^{* * *}$ & 0.392 \\
\hline MARKET & -0.233 & 0.184 & -0.146 & 0.121 & -0.177 & 0.172 & -0.295 & 0.284 & -0.011 & 0.041 & $-0.154^{*}$ & 0.083 \\
\hline GDPcap & $0.016^{* * *}$ & 0.005 & $0.015^{* * *}$ & 0.004 & $0.014^{* * *}$ & 0.004 & $0.014^{* *}$ & 0.004 & $0.020^{* *}$ & 0.009 & $0.012^{* * *}$ & 0.003 \\
\hline POPdensity & 0.234 & 0.177 & 0.067 & 0.142 & 0.085 & 0.059 & 0.190 & 0.202 & 0.184 & 0.124 & $0.174^{*}$ & 0.098 \\
\hline WEST & $-1.433^{* *}$ & 0.618 & -0.869 & 0.572 & $-0.699^{* *}$ & 0.363 & $-1.697^{* * *}$ & 0.461 & $-1.049^{*}$ & 0.624 & -1.403 & 0.899 \\
\hline EAST & 0.448 & 0.452 & 0.515 & 0.510 & 0.471 & 0.304 & 0.474 & 0.484 & 0.456 & 0.486 & 0.660 & 0.526 \\
\hline
\end{tabular}

${ }^{*}$ Significant at $10 \%$ level; ${ }^{* *}$ Significant at $5 \%$ level; ${ }^{* * *}$ Significant at $1 \%$ level.

All regressions allow for clustering by location-industry.

Heteroskedasticity-robust standard errors reported.

To account for the endogenous problems, a three-equation instrumental variables version of the ordered probit model is estimated, utilizing the CMP package for STATA 12.1 .

F-test on instruments is the test statistics on the F-test of the joint significance of the instruments (ICOLLEGE, IROA, IINTANG and IFIXSALE), with pvalues in braces. Hansen J-statistics is the test statistic on the overidentification test of instruments, with p-values in braces. 
Table 5 continued

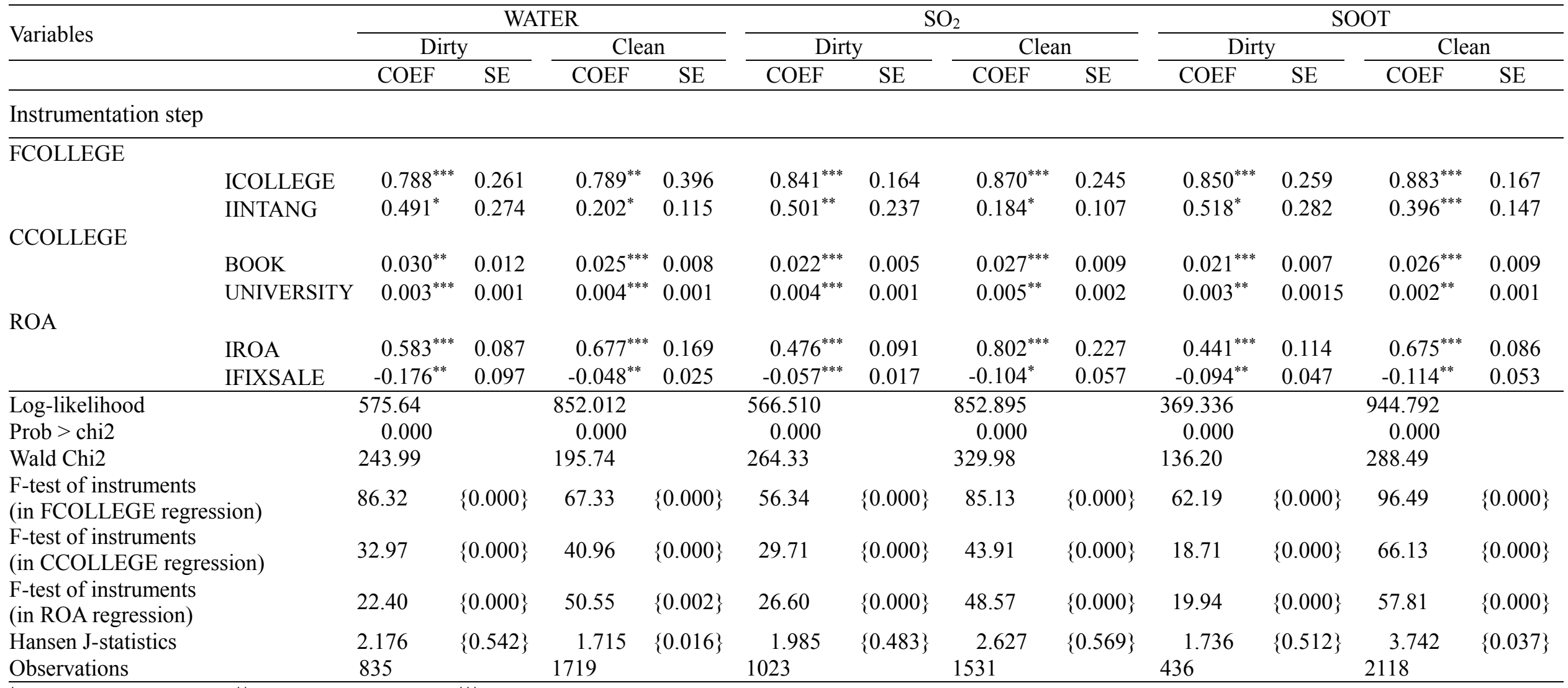

${ }^{*}$ Significant at $10 \%$ level; ${ }^{* *}$ Significant at $5 \%$ level; ${ }^{* * *}$ Significant at $1 \%$ level.

All regressions allow for clustering by location-industry.

Heteroskedasticity-robust standard errors reported.

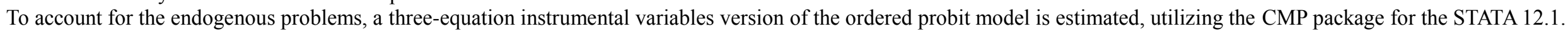

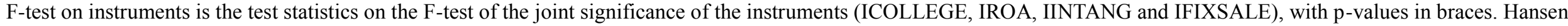

J-statistics is the test statistic on the overidentification test of instruments, with p-values in braces. 


\subsection{Marginal and interaction effects}

Neither the signs nor the magnitudes of the coefficients are directly interpretable in the ordered probit model. It is necessary to compute partial effects of something similar to interpret the model meaningfully. As mentioned by Mallick (2009) the marginal effect of a variable that is interacted with another variable differs from the marginal effect of a variable that is not interacted with any variable. Hence a direct application of the standard software (such as STATA 12) might lead to incorrect estimates of the magnitude and standard error of the interaction term in nonlinear models. Follow Mallick (2009), we calculate the consistent ordered probit marginal effects as well as interaction effects for interaction terms by assuming that the effects are evaluated at the mean values of repressors as shown in Table 6 and Table 7. ${ }^{4}$

Table 6 Marginal effects for firms' environmental compliance

\begin{tabular}{|c|c|c|c|c|c|c|}
\hline \multirow{2}{*}{ Variables } & \multicolumn{2}{|c|}{ Over-compliance } & \multicolumn{2}{|c|}{ Compliance } & \multicolumn{2}{|c|}{ Non-compliance } \\
\hline & ME & $\mathrm{SE}$ & $\mathrm{ME}$ & $\mathrm{SE}$ & ME & $\mathrm{SE}$ \\
\hline FCOLLEGE & $0.456^{* * *}$ & 0.155 & $0.258^{* * *}$ & 0.100 & $-0.714^{* * *}$ & 0.198 \\
\hline FSENIOR & 0.414 & 0.257 & $0.235^{*}$ & 0.139 & -0.648 & 0.400 \\
\hline FPRIMARY & $-0.407^{* *}$ & 0.182 & $-0.231^{* *}$ & 0.104 & $0.637^{* *}$ & 0.286 \\
\hline CCOLLEGE & $0.257^{* * *}$ & 0.046 & $0.145^{* * *}$ & 0.026 & $-0.402^{* * *}$ & 0.071 \\
\hline CSENIOR & -0.334 & 0.301 & 0.213 & 0.192 & 0.121 & 0.110 \\
\hline CPRIMARY & $-0.119^{* *}$ & 0.053 & $-0.067^{* *}$ & 0.031 & $0.187^{* *}$ & 0.085 \\
\hline Export & $0.048^{*}$ & 0.025 & $0.027^{*}$ & 0.014 & $-0.076^{* *}$ & 0.039 \\
\hline $\mathrm{RD}$ & $0.429^{* * *}$ & 0.153 & $-0.274^{* * *}$ & 0.100 & $-0.155^{* * *}$ & 0.057 \\
\hline SIZE & 0.022 & 0.014 & -0.014 & 0.009 & -0.008 & 0.005 \\
\hline AGE & -0.005 & 0.010 & 0.003 & 0.007 & 0.002 & 0.004 \\
\hline ROA & $0.090^{* *}$ & 0.041 & $0.051^{* *}$ & 0.023 & $-0.140^{* *}$ & 0.065 \\
\hline FDI & $0.087^{* * *}$ & 0.031 & $0.041^{* * *}$ & 0.014 & $-0.127^{* * *}$ & 0.043 \\
\hline Collective & -0.043 & 0.055 & 0.026 & 0.033 & 0.016 & 0.023 \\
\hline HMT & 0.016 & 0.029 & 0.010 & 0.018 & -0.026 & 0.047 \\
\hline Limited & -0.013 & 0.042 & 0.008 & 0.027 & 0.005 & 0.015 \\
\hline Private & 0.008 & 0.039 & -0.005 & 0.026 & -0.003 & 0.014 \\
\hline SOE & -0.008 & 0.051 & 0.005 & 0.033 & 0.003 & 0.019 \\
\hline AIRquality & $0.434^{* *}$ & 0.205 & $0.246^{*}$ & 0.128 & $-0.680^{*}$ & 0.354 \\
\hline UNEMP & $-0.104^{* * *}$ & 0.027 & $-0.059^{* * *}$ & 0.015 & $0.163^{* * *}$ & 0.041 \\
\hline INTso2 & $-0.106^{* *}$ & 0.046 & $0.068^{* *}$ & 0.032 & $0.038^{*}$ & 0.020 \\
\hline INTwater & -0.013 & 0.015 & -0.008 & 0.009 & 0.021 & 0.022 \\
\hline INTsoot & $-0.103^{* *}$ & 0.044 & $0.066^{*}$ & 0.034 & $0.037^{*}$ & 0.019 \\
\hline MARKET & -0.064 & 0.051 & 0.041 & 0.044 & 0.023 & 0.025 \\
\hline GDPcap & $0.004^{* * *}$ & 0.001 & $0.002^{* * *}$ & 0.001 & $-0.006^{* * *}$ & 0.001 \\
\hline POPdensity & 0.047 & 0.039 & 0.027 & 0.023 & -0.074 & 0.060 \\
\hline WEST & $-0.397^{*}$ & 0.225 & 0.139 & 0.090 & $0.258^{*}$ & 0.131 \\
\hline EAST & 0.118 & 0.115 & 0.117 & 0.120 & -0.235 & 0.220 \\
\hline
\end{tabular}

${ }^{*}$ Significant at $10 \%$ level $;{ }^{* *}$ Significant at $5 \%$ level; ${ }^{* *}$ Significant at $1 \%$ level.

ME: Marginal effect on probabilities averaged over all observations; SE, standard error of the ME

Marginal effects are calculated at the sample means according to Mallick (2009). Standard errors are calculated with the delta method. MEs are calculated based on the results of conditional mixed process (CMP) regression.

\footnotetext{
${ }^{4}$ The marginal and interaction effects have different signs for different observations, this issue can be avoided by assuming that the effect are evaluated at the mean value of explanatory variables (Ai and Norton, 2003)
} 
Table 6 depicts marginal effects for an ordered probit of the estimation of environmental performances of industrial firms. It shows the implied effect of explanatory variables, and the associated standard errors of the marginal effect, on the probabilities of all three environmental behaviors. The positive effect of COLLEGE in Table 4 translates into positive marginal effects for Over-compliance and compliance but negative effect for the non-compliance firms, all of which are statistically significant (Table 6). In particular, a 10\% rise in FCOLLEGE increases probabilities of over-compliance and compliance with environmental regulations by 0.046 and 0.026 respectively, but decreases probability of non-compliance by 0.071 . The marginal increase in FSENIOR only increases the probability of compliance by $23.5 \%$ but this effect is just weakly significant at $10 \%$ significant level. When education level of employees becomes lower, a marginal increase in FPRIMARY decreases the probabilities of over-compliance and compliance by $40.7 \%$ and $23.1 \%$ respectively but for non-compliance the probability increases by $63.7 \%$. In terms of external effect of human capital, we can find a marginal increase in the share of college educated population (CCOLLEGE) leads to an increase in probabilities of over-compliance and compliance by 0.257 and 0.145 respectively but decrease the probability of non-compliance by almost 0.402 . When it comes to the share of primary school educated population, the result is opposite. The marginal effects of CPRIMARY on the probability of over-compliance, compliance and non-compliance are $-0.119,-0.067$ and 0.187 respectively. However, we cannot find significant marginal effect of external senior school educated population on environmental performance of firms.

As for other firm level characteristics, we can find that compliance probabilities are also significantly related to international linkage variables. Looking at the effects of export, Table 6 shows that, on average, being an export-oriented firm is more likely to be over-compliance and compliance. A $10 \%$ increase in export increases the probabilities of over-compliance by 5 percentage points. In terms of ownership, Table 7 indicates that, relative to the reference group of public firms, firms with foreign ownership are $8.7 \%$ and $4.1 \%$ respectively, more likely to be over-compliance and compliance group, but $12.7 \%$ less likely to compliance with environmental regulations. A marginal increase in $\mathrm{R} \& \mathrm{D}$ expenditure increases the probability of being overcompliance by 0.429 and for compliance and non-compliance it decreases 0.274 and 0.155 respectively. A possible explanation for the result that $R \& D$ expenditure is negatively associated with firms' compliance behavior is the following. Those firms (with just compliance) which have more expenditure on R\&D may cut the budget on investment in pollution abatement and treatment. A further firm-internal factor that significantly associated with environmental behavior of firms is ROA. A marginal increase in ROA increases the probabilities of being overcompliance and compliance by 0.09 and 0.05 respectively but decreases the probability of noncompliance by 0.14 .

Turning to the sector characteristics, Table 6 indicates that, firms in $\mathrm{SO}_{2}$-intensive and sootintensive industries are less likely to be over-compliance but they are more likely to be compliance and non-compliance. For firms in $\mathrm{SO}_{2}$-intensive industries, other explanatory factors being controlled equal, they are $10.6 \%$ less likely to being over-compliance but more likely to being compliance and non-compliance by $6.8 \%$ and $3.8 \%$ respectively. Being included in sootintensive industries, on average, decreases the probabilities of over-compliance by $10.3 \%$ but increases the probabilities of compliance and non-compliance by $6.6 \%$ and $3.7 \%$ respectively.

In terms of our city and regional characteristics included in the model, we find that being located in cities with higher income and lower unemployment ratio, firms tend to be more likely to over-compliance and compliance with environmental regulations. Firms that located in high unemployment cities have the higher chance of being in the non-compliance group. $10 \%$ increase in unemployment ratio of a city increases the probability of infringing environmental regulations by $1.63 \%$ for firms in this city. This finding is coherent to the conclusion of some existing studies 
discussing the impact of industrial activities on environmental quality in China, as Cole et al. (2008b), who find that a region with a high unemployment rate would tend to have relax environmental regulations and attract more pollution intensive industries. Other factors being equal, 1 unit increase in GDP per capita of cities increases the probabilities of over-compliance and compliance by $0.4 \%$ and $0.2 \%$ respectively for firms located in those cities, but decreases the probability of non-compliance by $0.6 \%$. A marginal increase in ratio of days with good air quality within one year increases the probabilities of being over-compliance and compliance by 0.434 and 0.246 respectively. For other regional dummies, on average, being located in the west decrease the probability of over-compliance and increase the probability of non-compliance, but the probability of compliance does not seem to be much related to the western location.

The interaction effects of interaction terms as shown in Table 7 suggest that college educated population are more sensitive to environmental quality and are likely to impose greater pressure on the stringency of regulations to impel firm over-comply and comply with environmental regulations. While the primary school and below educated is more likely to induce government to relax the environmental regulation, resulting in environmental non-compliance. As for senior school educated population, they are not more sensitive to environmental quality as compared to the reference group (the junior school educated population).

Table 7 Magnitudes of the interaction effects

\begin{tabular}{|c|c|c|c|c|c|c|}
\hline \multirow{2}{*}{ Interaction } & \multicolumn{2}{|c|}{ Over-compliance } & \multicolumn{2}{|c|}{ Compliance } & \multicolumn{2}{|c|}{ Non-compliance } \\
\hline & IE & $\mathrm{SE}$ & IE & $\mathrm{SE}$ & IE & $\mathrm{SE}$ \\
\hline AIRCOLLEGE & $2.089^{* * *}$ & 0.711 & $1.184^{* * *}$ & 0.440 & $-3.273^{* * *}$ & 1.133 \\
\hline AIRSENIOR & 1.173 & 0.747 & 0.665 & 0.398 & -1.838 & 1.178 \\
\hline AIRPRIMARY & $-1.432^{* *}$ & 0.642 & $-0.812^{* *}$ & 0.374 & $2.244^{* *}$ & 1.025 \\
\hline
\end{tabular}

${ }^{*}$ Significant at $10 \%$ level; ${ }^{* *}$ Significant at $5 \%$ level $;{ }^{* * *}$ Significant at $1 \%$ level.

IE: Interaction effect on probabilities averaged over all observations; SE, standard error of the IE

Magnitudes of the interaction terms are obtained according to Mallick (2009). Standard errors are calculated with the delta method. MEs are calculated based on the results of conditional mixed process (CMP) regression.

\section{Concluding Remarks}

In this paper, we have empirically examined the internal and external effects of human capital on environmental compliance by using the real environmental performance data of Chinese industrial firms. Our estimation shows that firms' compliance decisions are not only affected by their internal endowment of human capital, but also impacted by the external stock of social human capital. Firms with high human capital are more likely to have better environmental compliance. The study also finds that highly educated local population (CCOLLEGE) contributes firms' environmental performance. In contrast, a low level of education in the local population (CPRIMARY) is associated with poorer compliance. The results are still significant after we give thought to the possible endogeneity of both internal and external human capital. However, for clean industries, our results demonstrate that the variation in external human capital is a better determinant of the firms' environmental performances than is the variation in internal human capital. We do not find supporting evidence for the internal effect of human capital in $\mathrm{SO}_{2}$ related and SOOT-related clean industries when we decompose our data into dirty and clean sectors by pollution intensity of industries in the terms of industrial polluted water emission, industrial $\mathrm{SO}_{2}$ emission and industrial soot emission.

The findings in this study have important policy implications. The role of city-wide human capital levels in compliance suggests that there is a positive externality from education. More generally, evidence from this study suggests that the situation of weak implementation of environmental supervision and evasion of environmental monitoring could be reconciled by 
internal and external effects of human capital. On the regulator side, a strategy of boosting the educational attainment of the population may be recommended to pull firms into better environmental compliance. On the firm side, raising human capital may induce improved environmental performance.

Although we have established the importance for compliance of external human capital, we do not know the exact route by which higher education levels influence firm behavior. It could be that human capital levels in the regulatory agency track general education level and so city-level human capital is a proxy for the human capital of the environmental agency. Alternatively, it could be individuals with higher education levels are more sensitive to compliance and/or more efficient in making complaints, lobbying for controls and prompting investigations into compliance. This is an issue that requires further research. 


\section{References}

Ai CR and Norton EC. (2003). Interaction terms in logit and probit models. Economics Letters, $80(1), 123-129$.

Blackman A and Kildegaard A. (2010). Clean Technological Change in Developing Country Industrial Clusters: Mexican Leather Tanneries. Environmental Economics and Policy Studies, 12(3), 115-132.

Blackman A and Bannister GJ. (1998). Community Pressure and Clean Technology in the Informal Sector: An Econometric Analysis of the Adoption of Propane by Traditional Mexican Brickmakers. Journal of Environmental Economics and Management, 35(1), 121.

Christmann P and Taylor G. (2001). Globalization and the environment: determinants of firm self-regulation in China. Journal of International Business Studies , 32(3), 439-458.

Cole MA, Elliott RJR and Shimamoto K. (2005). Industrial characteristics, environmental regulations and air pollution: an analysis of the UK manufacturing sector. Journal of Environmental Economics and Management, 50(1), 121-143.

Cole MA, Elliott RJR and Strobl E. (2008a). The environmental performance of firms: The role of foreign ownership, training, and experience. Ecological Economics, 65(3), 538-546.

Cole MA, Elliott RJR and Wu SS. (2008b). Industrial Activity and the Environment in China:An Industry-Level Analysis. China Economic Review, 19(3), 393-408.

Dasgupta S and Wheeler D. (1997). Citizen complaints as environmental indicators : evidence from China. Policy Research Working Paper Series 1704.

Dasgupta S, Hettige H and Wheeler D. (2000). What improve Environmental Compliance? Evidence from Mexican Industry. Journal of Environmental Economics and Management, 39(1), 39-66.

Dasgupta S, Laplante B, Mamingi N and Wang H. (2001). Inspections, pollution prices, and environmental performance: evidence from China. Ecological Economics, 36(3), 487-498.

Fischel WA. (1979). Determinants of voting on environmental quality: A study of a New Hampshire pulp mill referendum. Journal of Environmental Economics and Management, 6(2), 107-118.

Fisman R and Svensson J. (2007). Are corruption and taxation really harmful to growth? Firm level evidence. Journal of Development Economics, 83(1), 63-75.

Galdeano-Gómez E. (2010). Exporting and Environmental Performance: A Firm-level Productivity Analysis. The World Economy, 33(1), 60-88.

Gangadharan L. (2006). Environmental compliance by firms in the manufacturing sector in Mexico. Ecological Economics, 59(4), 477-486.

Goetz SJ, Debertin DL and Pagoulatos A. (1998). Human capital, Income, and Environmental Quality: A State-level Analysis. Agriculture and Resource Economics Review, 27(2), 200-208.

Goldar B and Banerjee N. (2004). Impact of Informal Regulation of Pollution on Water Quality in Rivers in India. Journal of Environmental Management, 73(2), 117-130. 
Grolleaua G, Mzoughib M and Pekovicc S. (2012). Green not (only) for profit: An empirical examination of the effect of environmental-related standards on employees'recruitment. Resource and Energy Economics, 34(1), 74-92.

Halkos GE and Evangelinos KI. (2002). Determinants of Environmental Management. Business Strategy and the Environment, 11(6), 360-375.

Mallick D. (2009). Marginal and interaction effects in ordered response models. Technical report, School of Accounting, Deakin University, Economics and Finance, Burwood.

Manderson E and Kneller R. (2012). Environmental Regulations, Outward FDI and Heterogeneous Firms: Are Countries Used as Pollution Havens? Environmental \& Resource Economics, European Association of Environmental and Resource Economists, 51(3), 317-352.

Mani M and Wheeler D. (1998). In search of pollution heavens? Dirty Industry in the world economy, 1960 to 95. Journal of Environment and Development, 7(3), 215-247.

Mzoughi N, Pekovic S and Grolleau G. (2007). Chemical Firms' Registration for the Responsible Care Program and the ISO 14001 Standard: A Comparative Approach. Economics Bulletin, 29(12), 1-13.

Nelson RR and Phelps ES. (1966). Investment in Humans, Technological Diffusion, and Economics Growth. American Economic Review, 56(2), 67-75.

Pargal S and Wheeler D. (1996). Informal Regulation of Industrial Pollution in Developing Countries: Evidence From Indonesia. Journal of Political Economy, 104(6), 1314-1327.

SEPA(State Environmental Protection Administration). (2004). Technical Guidelines for Enterprise Environment Behavior Evaluation. Beijing: SEPA.

SEPA(State Environmental Protection Administration). (2006). The Environmental Protection in China: 1996-2005 (White Book). Beijing: SEPA.

Wang $\mathrm{H}$ and Wheeler D. (2005). Financial incentives and endogenous enforcement in China's pollution levy system. Journal of Envionmental Economics and Management, 49(1), 174196.

Wang H, Mamingi N, Laplante B and Dasgupta S. (2003). Incomplete enforcement of pollution regulation: bargaining power in Chinese factories. Environmental \& Resource Economics, European Association of Environmental and Resource Economists, 24(3), 245-262.

Yang X and Yao Y. (2012). Environmental Compliance and Firm Performance: Evidence from China. Oxford Bulletin of Economics and Statistics, 74(3), 397-424. 


\section{Appendix}

Table A1 Indicators Assessing Firm Environmental Behavior

\begin{tabular}{lll}
\hline No. Indicator & Note \\
\hline 1 & Emission compliance & $\begin{array}{l}\text { The rate of emission compliance of major controlled pollutants from } \\
\text { all outlets should be greater than and equal to } 80 \% \text { or the average } \\
\text { concentration of major controlled pollutants should comply with } \\
\text { relevant emission standards. The rate of disposal/utilization of } \\
\text { hazardous wastes should be } 100 \% .\end{array}$ \\
\hline 2 & $\begin{array}{l}\text { Repeated occurrence of } \\
\text { environmental non-compliance }\end{array}$ & $\begin{array}{l}\text { The ratio of non-compliance to the frequency of environmental } \\
\text { inspection and monitoring is greater and equal to 50\%. }\end{array}$ \\
\hline & Total volume control & $\begin{array}{l}\text {-Firm which holds pollutant discharge permit should comply with } \\
\text { the requirements of the permit. } \\
\text {-Firm which do not have pollutant discharge permit should comply } \\
\text { with emission standards. }\end{array}$ \\
\hline 4 & Administrative penalty & $\begin{array}{l}\text { Firm has one or more records of non-compliance according to on- } \\
\text { site environmental inspection. }\end{array}$ \\
\hline
\end{tabular}

i) General accident: once or more times occurrence of pollution accident with direct economic loss over 1000 RMB and lower than $10000 \mathrm{RMB}$.

ii) Serious accident (at least one of the following four situations):

-Direct economic loss caused by the accident is greater than 10000

RMB and lower than $50000 \mathrm{RMB}$;

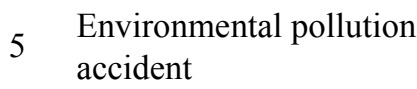

-Poisoning symptom occurred;

-Conflicts among citizens and the firm caused by the accident

- The accident causes environmental damage.

iii) More serious accident (at least one of the following situations)

-Direct economic loss caused by the accident is greater than 50000

RMB and lower than 100000 RMB;

-The poisoning occurred leads to potential permanent disability;

iv) The most serious accident: direct economic loss caused by the accident is greater than $100000 \mathrm{RMB}$.

\begin{tabular}{lll}
\hline 6 & $\begin{array}{l}\text { On-time payment of pollution } \\
\text { levy }\end{array}$ & $\begin{array}{l}\text { Firm pays for pollution levy on time in at least 70\% of twelve } \\
\text { months of a year and pays for pollution levy within 2 months in the } \\
\text { left months of a year. }\end{array}$ \\
\hline 7 & On-time reporting of emissions & $\begin{array}{l}\text { Firm finishes annual reporting of emissions on time. The Firm, } \\
\text { which holds pollutant discharge permit, reports its monthly } \\
\text { emissions on time. }\end{array}$ \\
\hline 8 & Standardized emission outlet & $\begin{array}{l}\text {-The emission outlets should be checked and accepted by EPB if the } \\
\text { Firm has the liability of pollution abatement. } \\
\text {-The emission outlets if not specified should be standardized. }\end{array}$ \\
\hline & $\begin{array}{l}\text { Implementation of the System } \\
\text { of "Three Synchronous }\end{array}$ & $\begin{array}{l}\text {-Firm should conduct environmental protection preliminary hearing } \\
\text { on time when proposes the project. }\end{array}$ \\
$\begin{array}{l}\text { Requirements" and } \\
\text { environmental management } \\
\text { procedure for construction } \\
\text { projects }\end{array}$ & $\begin{array}{l}\text {-Firm should conduct environmental impact assessment on time } \\
\text { when conducts the feasibility study. } \\
\text {-Firm complies with the requirements defined by Regulation of } \\
\text { Environmental Management of Construction Project. }\end{array}$ \\
\hline $\begin{array}{l}\text { Environmental organization } \\
\text { Environmental protection staff } \\
\text { Environmental management } \\
\text { system }\end{array}$ & $\begin{array}{l}\text { Firm has environmental organization. } \\
\text { Firm has full-time or part-time environmental protection staff. } \\
\text { Firm has corporate environmental management systems to fulfill } \\
\text { corporate environmental management task. }\end{array}$ \\
\hline
\end{tabular}




\section{Table A1 Continued}

No. Indicator Note

Comprehensive utilization rate of Disposal rate of industrial solid wastes should be $100 \%$ and the

11 industrial solid wastes greater than comprehensive utilization rate of industrial solid wastes greater or equal to $80 \%$ than or equal to $80 \%$.

12 Repeated occurrence of public complains

The municipal government receives more three times of public complains and corporate environmental performance causes certain environmental impacts and damage.

13 Occurrence of public complain The municipal government receives once public complain and corporate environmental performance causes certain environmental impacts.

Firm passes cleaner production audit and corporate

14 Cleaner production environmental management reaches domestic top level and advanced international level.

$15 \quad$ ISO 14000 certification Firm passes ISO 14000 certification and gains certificate. 
Figure A1 Conceptual Scheme of the Grading System

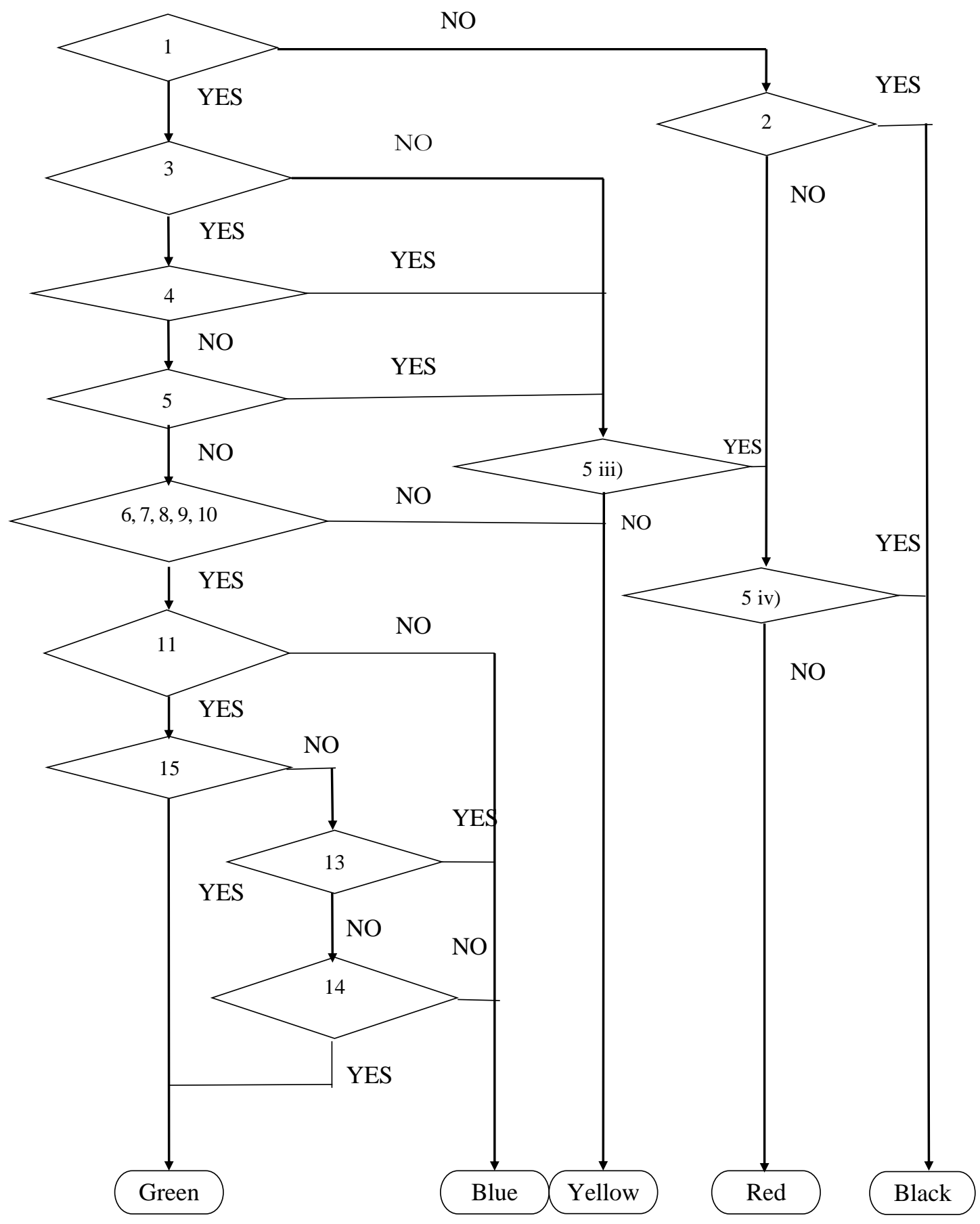

Note: $1,2,3,4,5,6,7,8,9,10,11,13,14,15$ represent 15 indicators assessing firms' environmental performances in Table A1. 
Table A1 Information of dropped data

\begin{tabular}{|c|c|c|c|c|c|c|c|}
\hline CITY & Green & Blue & Yellow & Red & Black & Total & $\begin{array}{l}\text { Percen } \\
\mathrm{t}\end{array}$ \\
\hline Changde & 0 & 1 & 0 & 0 & 0 & 1 & 0.1 \\
\hline Changzhou & 0 & 1 & 1 & 0 & 0 & 2 & 0.2 \\
\hline Chaohu & 1 & 3 & 0 & 0 & 0 & 4 & 0.3 \\
\hline Chongqing & 0 & 2 & 0 & 1 & 0 & 3 & 0.3 \\
\hline Hangzhou & 19 & 52 & 41 & 2 & 0 & 114 & 9.7 \\
\hline Huaibei & 2 & 9 & 1 & 0 & 0 & 12 & 1.0 \\
\hline Huainan & 0 & 7 & 10 & 0 & 0 & 17 & 1.4 \\
\hline Huhehot & 4 & 12 & 7 & 0 & 0 & 23 & 2.0 \\
\hline Jiaozuo & 0 & 1 & 2 & 0 & 0 & 3 & 0.3 \\
\hline Jiayuguan & 0 & 0 & 0 & 0 & 0 & 0 & 0.0 \\
\hline Jinan & 1 & 4 & 3 & 1 & 0 & 9 & 0.8 \\
\hline Liuzhou & 2 & 16 & 9 & 0 & 0 & 27 & 2.3 \\
\hline Maanshan & 0 & 4 & 3 & 0 & 0 & 7 & 0.6 \\
\hline Nanjing & 37 & 92 & 88 & 9 & 2 & 228 & 19.4 \\
\hline Nantong & 7 & 11 & 13 & 0 & 1 & 32 & 2.7 \\
\hline Ningbo & 23 & 102 & 59 & 2 & 0 & 186 & 15.8 \\
\hline Suzhou & 34 & 122 & 102 & 6 & 1 & 265 & 22.6 \\
\hline Taizhou & 4 & 16 & 6 & 1 & 2 & 29 & 2.5 \\
\hline Tongling & 7 & 22 & 10 & 3 & 0 & 42 & 3.6 \\
\hline Wenzhou & 2 & 6 & 4 & 0 & 0 & 12 & 1.0 \\
\hline Wuxi & 8 & 21 & 9 & 4 & 1 & 43 & 3.7 \\
\hline Xuzhou & 0 & 7 & 7 & 3 & 2 & 19 & 1.6 \\
\hline Yancheng & 2 & 5 & 4 & 1 & 0 & 12 & 1.0 \\
\hline Yangzhou & 0 & 3 & 8 & 0 & 0 & 11 & 0.9 \\
\hline Yantai & 0 & 1 & 1 & 0 & 0 & 2 & 0.2 \\
\hline Zhenjiang & 9 & 19 & 17 & 2 & 1 & 48 & 4.1 \\
\hline Zhuzhou & 0 & 4 & 4 & 0 & 1 & 9 & 0.8 \\
\hline Zibo & 1 & 3 & 8 & 2 & 1 & 15 & 1.3 \\
\hline Total & 163 & 546 & 417 & 37 & 12 & 1175 & \\
\hline$\%$ of firms & & & & & & & \\
\hline $\begin{array}{l}\text { in each } \\
\text { level }\end{array}$ & 13.9 & 46.5 & 35.5 & 3.1 & 1.0 & & \\
\hline
\end{tabular}


Table A3 Variables and definitions

\begin{tabular}{|c|c|c|c|}
\hline \multicolumn{2}{|l|}{ Variables } & Definition & Source \\
\hline \multicolumn{2}{|c|}{ Environmental compliance } & $\begin{array}{l}=2 \text { if the firm environmental behavior is evaluated as "blue" and "green"; }=1 \text { if the } \\
\text { firm's environmental behavior is evaluated as "yellow"; }=0 \text { otherwise }\end{array}$ & (4) \\
\hline \multirow{8}{*}{$\begin{array}{l}\text { Human capital } \\
\text { variables }\end{array}$} & FCOLLEGE & share of college educated (and above) employees in the firm & (1) \\
\hline & FSENIOR & share of employees with senior high school education in the firm & \\
\hline & FJUNIOR & share of employees with junior high school education in the firm & (1) \\
\hline & FPRIMARY & share of employees with primary school education (and below) in the firm & (1) \\
\hline & CCOLLEGE & share of college educated (and above) population in the city & (5) \\
\hline & CSENIOR & share of senior high school educated population in the city & \\
\hline & CJUNIOR & share of junior high school educated population in the city & (5) \\
\hline & CPRIMARY & share of primary school educated (and below) population in the city & (5) \\
\hline \multirow{13}{*}{$\begin{array}{l}\text { Firm-level } \\
\text { variables }\end{array}$} & $\mathrm{RD}$ & $\mathrm{R} \& \mathrm{D}$ expenditure/sales & (1) \\
\hline & SIZE & the logarithm of the number of employees by the end of the year & (1) \\
\hline & Age & The age of the firm & (1) \\
\hline & Exports & Total export/total sales & (1) \\
\hline & ROA & Earnings before interest and tax EBIT/Total Assets & (1) \\
\hline & & Dummy variable $=1$ if the firm is registered as joint ventures, cooperative with Hong & \\
\hline & HMT & $\begin{array}{l}\text { Kong, Macau, Taiwan investors, or HMT wholly owned companies, or HMT } \\
\text { shareholding limited companies; =0, otherwise }\end{array}$ & (1) \\
\hline & FDI & $\begin{array}{l}\text { Dummy variable, }=1 \text { if the firm is registered as joint ventures, cooperative with foreign } \\
\text { investors, or wholly foreign owned companies, or foreign shareholding limited } \\
\text { companies; =0, otherwise }\end{array}$ & (1) \\
\hline & SOE & $\begin{array}{l}\text { Dummy variable, }=1 \text { if the firm is registered as state-owned enterprises, including } \\
\text { alliances of SOEs and unlisted state-owned limited companies; }=0 \text {, otherwise }\end{array}$ & (1) \\
\hline & Collective & $\begin{array}{l}\text { Dummy variable, }=1 \text { if the firm is registered as collectives or alliances of collectives; } \\
=0 \text {, otherwise. }\end{array}$ & (1) \\
\hline & Public & Dummy variable, $=1$ if the firm is a public listed company; $=0$, otherwise & (1) \\
\hline & Limited & $\begin{array}{l}\text { Dummy variable }=1 \text { if the firm is registered as unlisted non-state-owned limited } \\
\text { companies; }=0 \text {, otherwise. }\end{array}$ & (1) \\
\hline & Private & Dummy variable $=1$ if the firm is registered as private; $=0$, otherwise. & (1) \\
\hline \multirow{3}{*}{$\begin{array}{l}\text { Industry-level } \\
\text { variables }\end{array}$} & INTso2 & Industrial $\mathrm{SO}_{2}$ emission/industrial value added & (2)(3) \\
\hline & INTwater & Industrial waste water emission/industrial value added & (2)(3) \\
\hline & INTsoot & Industrial soot emission/industrial value added & (2)(3) \\
\hline \multirow{9}{*}{$\begin{array}{l}\text { Regional } \\
\text { variables }\end{array}$} & Market & $\begin{array}{l}\text { Measurement if marketization of province level from Marketization of China's } \\
\text { provinces } 2004 \text { report. Higher value indicates Higher entry barrier at province level. }\end{array}$ & (6) \\
\hline & Unemployment & Unemployment rate of the city & (5) \\
\hline & BOOK & Average number of books in public libraries in the city. & \\
\hline & UNIVERSITY & Number of universities and colleges in the city. & \\
\hline & AIRquality & Ratio of days with excellent or good air quality in urban areas in one year & (2) \\
\hline & POPdensity & Population density & (5) \\
\hline & WEST & Dummy variable, $=1$ if the firm is located in the western China; $=0$, otherwise & (5) \\
\hline & CENTER & Dummy variable, $=1$ if the firm is located in the central China; $=0$, otherwise & (5) \\
\hline & EAST & Dummy variable, $=1$ if the firm is located in the eastern China; $=0$, otherwise & (5) \\
\hline \multirow{3}{*}{ Interactions } & AIRCOLLEGE & Interaction between AIRquality and CCOLLEGE & (2)(5) \\
\hline & AIRSENIOR & Interaction between AIRquality and CSENIOR & (2)(5) \\
\hline & AIRJUNIOR & Interaction between AIRquality and CJUNIOR & (2)(5) \\
\hline
\end{tabular}

Data source:

(1) China industrial enterprises database (survey data 2005);

(2)China Environmental Statistics Yearbook (2005);

(3) China Industrial statistics yearbook (2005);

(4)EMP Environmental information disclosure system data (2004);

(5) China City Statistical Yearbook (2005);

(6) Marketization of China's provinces 2004 report. 
Table A4 Statistical description of the data (2004)

\begin{tabular}{|c|c|c|c|c|c|c|}
\hline Variable & Unit & Obs. & Mean & Std. Dev. & Min & Max \\
\hline FCOLLEGE & ratio & 2554 & 0.143 & 0.160 & 0.000 & 1.000 \\
\hline FSENIOR & ratio & 2554 & 0.374 & 0.220 & 0.000 & 1.000 \\
\hline FJUNIOR & ratio & 2554 & 0.483 & 0.287 & 0.000 & 1.000 \\
\hline FPRIMARY & ratio & 2554 & 0.017 & 0.012 & 0.000 & 0.276 \\
\hline CCOLLEGE & ratio & 2554 & 0.061 & 0.030 & 0.014 & 0.117 \\
\hline CSENIOR & ratio & 2554 & 0.132 & 0.028 & 0.061 & 0.243 \\
\hline CJUNIOR & ratio & 2554 & 0.351 & 0.033 & 0.295 & 0.469 \\
\hline CPRIMARY & ratio & 2554 & 0.456 & 0.048 & 0.327 & 0.613 \\
\hline AIRCOLLEGE & CCOLLEGE*AIRquality & 2554 & 0.047 & 0.025 & 0.006 & 0.095 \\
\hline AIRSENIOR & CSENIOR*AIRquality & 2554 & 0.276 & 0.051 & 0.147 & 0.416 \\
\hline AIRJUNIOR & CJUNIOR*AIRquality & 2554 & 0.363 & 0.083 & 0.138 & 0.533 \\
\hline Exports & ratio & 2554 & 0.171 & 0.307 & 0.000 & 1.000 \\
\hline $\mathrm{RD}$ & ratio & 2554 & 0.002 & 0.010 & 0.000 & 0.249 \\
\hline SIZE & $\log$ form of employment & 2554 & 5.595 & 1.206 & 1.792 & 10.843 \\
\hline AGE & year & 2554 & 1.061 & 1.152 & 0.069 & 19.340 \\
\hline ROA & ratio & 2554 & 0.045 & 0.108 & -1.628 & 1.108 \\
\hline IROA & ratio & 2554 & 0.049 & 0.055 & -0.240 & 0.637 \\
\hline FDI & dummy & 2554 & 0.177 & 0.382 & 0.000 & 1.000 \\
\hline Collective & dummy & 2554 & 0.052 & 0.223 & 0.000 & 1.000 \\
\hline HMT & dummy & 2554 & 0.121 & 0.326 & 0.000 & 1.000 \\
\hline Limited & dummy & 2554 & 0.170 & 0.376 & 0.000 & 1.000 \\
\hline Private & dummy & 2554 & 0.330 & 0.470 & 0.000 & 1.000 \\
\hline SOE & dummy & 2554 & 0.070 & 0.256 & 0.000 & 1.000 \\
\hline AIRquality & ratio & 2554 & 0.791 & 0.136 & 0.421 & 0.992 \\
\hline UNEMP & ratio & 2554 & 0.071 & 0.012 & 0.026 & 0.101 \\
\hline INTso2 & tonnes per million yuan of value added & 2554 & 0.027 & 0.046 & 0.0003 & 0.235 \\
\hline INTwater & $\begin{array}{l}1000 \text { tonnes per million yuan of value } \\
\text { added }\end{array}$ & 2554 & 0.061 & 0.086 & 0.002 & 0.373 \\
\hline INTsoot & tonnes per million yuan of value added & 2554 & 0.035 & 0.081 & 0.0003 & 0.312 \\
\hline MARKET & index & 2554 & 8.400 & 1.358 & 3.950 & 9.770 \\
\hline GDPcap & 1000 yuan per capita & 2554 & 35.155 & 14.561 & 6.495 & 57.992 \\
\hline POPdensity & 1000 people/sq.km & 2554 & 1.503 & 1.010 & 0.095 & 2.927 \\
\hline $\mathrm{BOOK}$ & books per person & 2554 & 0.466 & 0.369 & 0.100 & 2.000 \\
\hline UNIVERSITY & l & 2554 & 11.278 & 10.866 & 2.000 & 58.000 \\
\hline WEST & dummy & 2554 & 0.086 & 0.265 & 0.000 & 1.000 \\
\hline CENTER & dummy & 2554 & 0.172 & 0.280 & 0.000 & 1.000 \\
\hline EAST & dummy & 2554 & 0.742 & 0.364 & 0.000 & 1.000 \\
\hline
\end{tabular}


Table A5 Pollution intensities of industries 2004

\begin{tabular}{|c|c|c|c|c|c|c|}
\hline \multirow[b]{2}{*}{ Industrial sector } & \multicolumn{2}{|c|}{ WATER } & \multicolumn{2}{|c|}{$\mathrm{SO} 2$} & \multicolumn{2}{|c|}{ SOOT } \\
\hline & $\begin{array}{l}\text { Emission } \\
\text { intensity }\end{array}$ & Rank & $\begin{array}{l}\text { Emission } \\
\text { intensity }\end{array}$ & Rank & $\begin{array}{l}\text { Emission } \\
\text { intensity }\end{array}$ & Rank \\
\hline Electric \& Heating Power & 5938.63 & 8 & 23.49 & 1 & 8.42 & 2 \\
\hline Electronic Machinery and Equipment & 298.99 & 32 & 0.05 & 34 & 0.05 & 33 \\
\hline Apparel, Shoes, and Hat Manufacturing & 1007.00 & 27 & 0.11 & 30 & 0.07 & 31 \\
\hline Textile & 6475.27 & 6 & 1.24 & 15 & 0.53 & 18 \\
\hline Mining and Processing of Nonmetal Ores & 6136.10 & 7 & 2.38 & 11 & 6.05 & 3 \\
\hline Nonmetallic Minerals Products & 2097.00 & 21 & 7.67 & 2 & 31.16 & 1 \\
\hline Recycling & 1522.35 & 22 & 0.45 & 21 & 0.40 & 19 \\
\hline Handicraft Article & 244.96 & 34 & 0.04 & 35 & 0.05 & 32 \\
\hline Mining \& Processing of Ferrous Metal Ores & 5458.91 & 10 & 2.18 & 12 & 2.11 & 11 \\
\hline Smelting and Pressing of Ferrous Metals & 4347.55 & 12 & 2.64 & 10 & 4.08 & 4 \\
\hline Chemical Fibers & 11829.49 & 4 & 2.89 & 8 & 0.98 & 16 \\
\hline Chemical Materials \& Chemical Products & 9466.92 & 5 & 3.03 & 7 & 1.99 & 12 \\
\hline Furniture & 201.34 & 35 & 0.09 & 31 & 0.07 & 30 \\
\hline Transportation Equipment & 1170.13 & 26 & 0.16 & 28 & 0.32 & 22 \\
\hline Metal Product & 1192.70 & 24 & 0.24 & 26 & 0.19 & 24 \\
\hline Coal Mining and Washing & 2745.22 & 17 & 0.84 & 18 & 1.50 & 13 \\
\hline Wood Processing and Product & 2358.70 & 19 & 1.26 & 14 & 2.14 & 10 \\
\hline Agricultural \& By-Product & 5337.27 & 11 & 0.92 & 17 & 1.38 & 14 \\
\hline Leather, Fur, Feather and Related Products & 2333.75 & 20 & 0.24 & 25 & 0.19 & 25 \\
\hline Natural Gas Production and Distribution & 12898.58 & 2 & 4.12 & 5 & 2.61 & 8 \\
\hline Petroleum & 3499.49 & 16 & 3.87 & 6 & 3.54 & 5 \\
\hline Food Manufacturing & 4321.34 & 13 & 0.96 & 16 & 0.62 & 17 \\
\hline Production and Distribution of Water & 5511.33 & 9 & 0.29 & 23 & 0.11 & 28 \\
\hline Plastics & 281.01 & 33 & 0.12 & 29 & 0.09 & 29 \\
\hline Communication Equipment & 303.24 & 31 & 0.03 & 36 & 0.03 & 36 \\
\hline General Machinery & 892.41 & 28 & 0.30 & 22 & 0.31 & 23 \\
\hline Rubber & 1271.57 & 23 & 0.81 & 19 & 0.35 & 21 \\
\hline Tobacco Products & 168.77 & 36 & 0.07 & 32 & 0.04 & 34 \\
\hline Medicines & 3652.88 & 15 & 0.76 & 20 & 0.39 & 20 \\
\hline Stationery and Sporting Goods & 1182.39 & 25 & 0.23 & 27 & 0.11 & 27 \\
\hline Beverage Manufacturing & 3753.42 & 14 & 1.27 & 13 & 1.10 & 15 \\
\hline Printing and Recording Media Reproducing & 342.81 & 30 & 0.05 & 33 & 0.04 & 35 \\
\hline Non-Ferrous Metal Ore Mining & 12036.19 & 3 & 2.66 & 9 & 2.38 & 9 \\
\hline Smelting \& Pressing of Non-ferrous Metals & 2565.46 & 18 & 5.08 & 3 & 2.82 & 7 \\
\hline Paper and Paper Products & 37305.11 & 1 & 4.57 & 4 & 2.84 & 6 \\
\hline Special Machinery & 855.73 & 29 & 0.26 & 24 & 0.17 & 26 \\
\hline
\end{tabular}

Note: pollution intensities are measured as tonnes per million yuan of industrial value added 